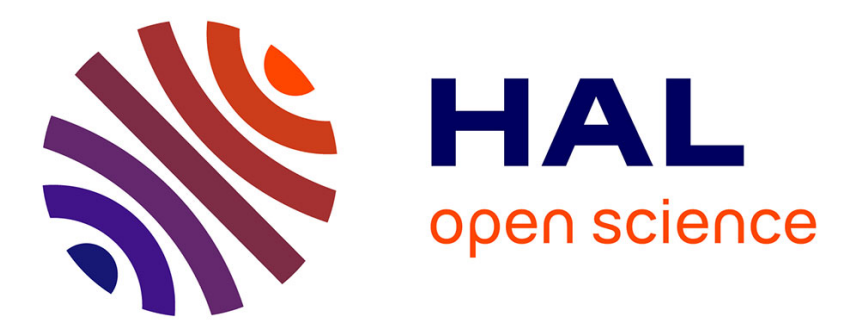

\title{
The Scope for Postmating Sexual Selection in Plants
}

Jeanne Tonnabel, Patrice David, Tim Janicke, Arnaud Lehner, Jean-Claude

Mollet, John Pannell, Mathilde Dufay

\section{To cite this version:}

Jeanne Tonnabel, Patrice David, Tim Janicke, Arnaud Lehner, Jean-Claude Mollet, et al.. The Scope for Postmating Sexual Selection in Plants. Trends in Ecology \& Evolution, 2021, 36 (6), pp.556-567. 10.1016/j.tree.2021.02.013 . hal-03190294

\section{HAL Id: hal-03190294}

\section{https://hal-normandie-univ.archives-ouvertes.fr/hal-03190294}

Submitted on 27 Nov 2021

HAL is a multi-disciplinary open access archive for the deposit and dissemination of scientific research documents, whether they are published or not. The documents may come from teaching and research institutions in France or abroad, or from public or private research centers.
L'archive ouverte pluridisciplinaire HAL, est destinée au dépôt et à la diffusion de documents scientifiques de niveau recherche, publiés ou non, émanant des établissements d'enseignement et de recherche français ou étrangers, des laboratoires publics ou privés. 
3 Jeanne Tonnabel ${ }^{1 *}$, Patrice David ${ }^{1}$, Tim Janicke ${ }^{1,2}$, Arnaud Lehner ${ }^{3}$, Jean-Claude Mollet ${ }^{3}$, John R.

4 Pannell ${ }^{4}$, Mathilde Dufay ${ }^{1}$

$5 \quad{ }^{1}$ CEFE, Univ Montpellier, CNRS, Univ Paul Valéry Montpellier 3, EPHE, IRD, Montpellier, France

$6 \quad{ }^{2}$ Applied Zoology, Technical University Dresden, Zellescher Weg 20b, 01062 Dresden, Germany.

$7 \quad{ }^{3}$ Normandie Univ, UNIROUEN, Laboratoire Glycobiologie et Matrice Extracellulaire Végétale

8 (GlycoMEV), SFR 4377 NORVEGE, IRIB, Carnot I2C, 76000 Rouen, France

$9 \quad{ }^{4}$ Department of Ecology and Evolution, University of Lausanne, 1015 Lausanne, Switzerland

$10 *$ jeanne.tonnabel@cefe.cnrs.fr

11 Short title : Sexual selection during pollen-pistil interactions 


\section{Abstract}

14 Sexual selection is known to shape plant traits that affect access to mates during the pollination

15 phase, but it is less well understood to what extent it affects traits relevant to interactions between

16 pollen and pistils after pollination. This is surprising, because both of the two key modes of sexual

17 selection, male-male competition and female choice, could plausibly operate during pollen-pistil

18 interactions where physical male-female contact occurs. Here, we consider how the key processes

19 of sexual selection might affect traits involved in pollen-pistil interactions, including 'Fisherian

20 runaway' and 'good-genes' models. We review aspects of the molecular and cellular biology of

21 pollen-pistil interactions on which sexual selection could act and point to research that is needed to

22 investigate them.

23 Key-words : sexual selection, pollen-pistil interactions, mate choice, genetic correlation, Fisherian

24 runaway, good-genes model 


\section{Scope for sexual selection in plants}

27 The concept of sexual selection (see Glossary) emerged with Darwin's [1] conjecture that selection

28 for accessing sexual partners could explain extravagant animal phenotypes. Two selective forces are 29 traditionally recognized in sexual selection theory: competition for access to the mate's gametes 30 (typically by males), and choice of sexual partners (typically by females). Remarkably, Darwin [1] 31 explicitly considered plants to fall beyond the reach of his theory. The main perceived obstacles to 32 applying sexual selection to plants was their frequent hermaphroditic nature, their lack of sensory 33 organs, and the modest levels of sexual dimorphism found in dioecious species [2]. Yet none of 34 these attributes precludes the action of sexual selection, as shown by recent empirical investigations 35 in animals [3-6]. Following much initial debate, plant evolutionary biologists have thus come to 36 reject Darwin's reticence to consider sexual selection for plants [2,7-13]. It is now accepted that 37 sexual selection may operate in all anisogamous organisms in which females produce larger but 38 fewer gametes than males, thus including both plants and hermaphrodites [14,15]. Revealingly, 39 Bateman [16] explicitly included flowering plants when setting out our modern perspective of how 40 to measure sexual selection, now known as the three Bateman principles. In accordance with 41 Bateman's third principle, male reproductive success showed a steeper relationship with the number 42 of genetic partners than female reproductive success in both a moss [17] and a flowering plant 43 species [18].

45 Plant populations display all necessary elements for the operation of sexual selection. For instance, 46 sexual dimorphism in gamete size and number, classically measured via pollen:ovule ratios, is 47 pervasive in flowering plants [19]. Examination of seed paternity within fruits in natural 48 populations has repeatedly found evidence for polyandry, with several pollen donors effectively 49 competing to sire ovules on a given plant [20]. Finally, variance in the reproductive success of 
50 pollen donors [21] can be related to various traits including those that influence pollen production

51 [22], the dispersal of pollen to pistils of potential sexual partners (during the pre-pollination phase)

52 [18], and the outcome of pollen competition in the pistil (during the post-pollination phase).

54 Most research on sexual selection in plants has involved investigating the transfer of pollen to 55 recipient stigmas. Selection during this pre-pollination phase most typically involves indirect 56 competition with other pollen donors, and acts on traits that affect the attraction of pollinators and 57 pollen export to mates (Fig. 1a) [23]. In general, these traits include both aspects of morphology and 58 phenology, e.g., selection of males that flower concomitantly to females (Fig. 1b) [24]. A case of 59 physical male-male competition was reported in the pre-pollination phase in the form of 'horns' 60 placed on structures that disperse pollen (pollinaria), preventing the attachment of pollen from rival 61 males to pollinators' bodies (Fig. 1c) [25]. Pollen morphology more generally has been shown to

62 affect the efficacy of attachment of pollen to pollinator bodies (Fig. 1d) [26]. Yet, despite these

63 revealing examples, we still have a surprisingly poor understanding of whether enhanced pollinator

64 attraction and/or pollen removal actually corresponds to an increased number of mates, the most

65 relevant parameter in theories of sexual selection. The first direct estimations of mate numbers in 66 plants identified increased clonal growth [17] and more slender plant architecture (Fig. 1e) [18,21]

67 as targets of sexual selection, because these traits promoted pollen dispersal over greater distances 68 to more numerous mates.

69

70 In contrast to our growing understanding of how sexual selection acts during the pre-pollination 71 phase, we know little about its operation after pollen has landed on the pistil (Fig. 1f). This 72 asymmetry is puzzling, for two reasons. First, the post-pollination phase represents the only 73 instance of direct contact between male and female mating partners where female choice might be 74 able to act, a mode of sexual selection that has received much attention from zoologists. Second, the 
post-pollination phase of mating represents an additional opportunity for the action of intra-sexual

76 competition between male gametophytes (the pollen grains and tubes). In contrast to the

77 accumulating evidence for intra-sexual competition operating during the pre-pollination phase, we

78 lack any sort of synthesis about the possibility that female choice might shape pollen traits, with

79 obvious parallels with post-copulatory selection in animals [27].

81 Several observations suggest that a search for evidence of sexual selection during the post-

82 pollination phase might be fruitful. Typically, many more pollen grains are deposited on stigmas

83 than the number of ovules in the corresponding ovaries [28 but see 29]. High pollen loads combined

84 with strong polyandry set the stage for intense sexual selection during pollen-pistil interactions.

85 Moreover, individual plants vary in several pollen competitive traits identified as key determinants

86 of variance in fertilization success (Table S1; [30]). These findings raise the question of the relative

87 importance of intra-sexual competition among pollen donors for accessing ovules, and inter-

88 sexual mate choice exerted by pistil tissues for explaining the observed variance in fertilization

89 success.

91 In this synthesis, we aim at reviewing knowledge about pollen-pistil interactions in the light of their

92 support for the occurrence of sexual selection in flowering plants. Strikingly, pistil tissues not only

93 facilitate the growth of pollen tubes by providing nutritive resources, but they also influence the

94 ability of pollen tubes to perceive the pistil cues that guide pollen towards the ovules [31-34].

95 Molecular knowledge about pollen-pistil interactions offers several candidates for the action of

96 sexual selection which we present in the light of their potential congruence with classical models of

97 sexual selection [35-39].

98

99 Pollen-pistil interactions in a nutshell: the active role of pistil tissues 
101 Pollen-pistil interactions have been the focus of fruitful research on plant mating in terms of self-

102 fertilization avoidance and the promotion of outcrossing, in fields ranging from theoretical and 103 empirical population genetics [40-42], to molecular genetics and cellular biology [43,44]. In this 104 sense, pollen-pistil interactions represent an area of biological enquiry that, unusually, links both 105 evolutionary and population-based thinking with functional considerations of mechanisms at the 106 molecular level. Other studies of pollen-pistil interactions are relevant to our understanding of asymmetries of mating between hybridising species $[45,46]$. Though rich in data and concept, most 108 of this work nonetheless has focused on questions not directly relevant to sexual selection. Yet 109 molecular biologists have recently uncovered a rather complex molecular dialogue between pollen 110 and pistil, with potential implications for sexual selection.

112 After their successful arrival on a pistil, pollen grains need to adhere to the stigma and to uptake 113 water to re-hydrate, germinate and produce a pollen tube (Fig. 2). The initial growth of pollen tubes 114 in the stigma is autotrophic, but becomes heterotrophic when reaching the style. Secretion of 115 nutritive molecules by pistils nourishes pollen tubes, which deplete nutritive molecules from the 116 stylar extracellular matrix (listed in Table S2). Although the mechanisms of the fuel transfer from 117 pistil to pollen tubes are not yet fully understood, it is clear that pistil cells modify their metabolism 118 in response to pollen tube growth [47], and that pollen tubes have evolved ways of harvesting pistil 119 nutritive resources [48]. Pistil tissues also secrete molecules facilitating pollen germination and 120 promoting pollen tube penetration (Table S2).

122 Stylar tissues also provide guidance cues that ensure the successful orientation of pollen tubes 123 towards the unfertilized ovules (Fig. 2; [49,50]). This process involves the very modification of 124 pollen tubes by the pistil to confer upon them a 'competence' to localize ovules [34,51]; remarkably, 
125 pollen tubes grown in vitro can locate dissected ovules only if they have previously navigated

126 through excised pistil tissues [33]. Accordingly, multiple changes in gene expression occur in pollen

127 tubes after their growth through pistil tissues, and vice versa $[47,52]$.

129 The final guidance of pollen tubes within the ovary is undoubtedly the best understood phase of

130 pistilar control, which is largely dependent on signals produced by the haploid female gametophyte

131 [34,53,54]. Ablation studies have shown that both the embryo sac and integuments of the ovule are 132 involved in pollen tube guidance within the ovary [55]. Synergid cells play a central role by 133 producing small peptides that re-orient the tip-focused pollen tube growth towards the embryo sac.

134 A complex dialogue between the synergids and the pollen tube further leads to the double 135 fertilization [32]. The expression of attractive peptides are then blocked, repellent ethylene is 136 produced to prevent more than one pollen tube from entering the ovule [56], and degeneration of 137 the remaining synergid is induced [57].

\section{Candidate pollen traits for intra-sexual competition}

141 Sexual selection theory predicts that increased competition for accessing mates selects for higher 142 investment in competitive traits [37]. This prediction may translate to pollen-pistil interactions 143 through selection for greater allocation to pollen competitive traits with increased number of 144 competing pollen donors. At the macroscopic scale, several studies indicate that certain pollen 145 phenotypes confer greater fertilization success than others, pointing to the action of intra-sexual 146 competition (Table S1). Yet we have little knowledge about the extent to which such within147 generation variance in fertilization ability has translated into pollen trait evolution. A handful of 148 studies have estimated heritabilities from $9 \%$ to $49 \%$ for male gametophyte traits [10,58-60]. 149 Studying the evolutionary consequences of variation in the number of pollen donors applied via 
150 hand-pollination in chinese innocence (Collinsia heterophylla), Lankinen et al. [61] observed

151 enhanced pollen performance in a line that evolved four generations under two pollen donor crosses 152 compared to a single pollen donor line.

154 Several molecular features of the ability of pollen to draw upon pistil resources and guidance cues

155 are obvious candidates for the action of male-male competition (Table S3 lists candidate molecules

156 for evolutionary testing). Pollen tube performance involves the expression of molecule transporters

157 [62], the constant reorganization of actin filaments [63], vesicle trafficking at the pollen tube apex

158 to build cell walls [64], active cell wall remodeling [65] and, sometimes, a plastic decrease in pollen

159 tube diameter to allow better movement between pistil cells [66]. Suppressing the growth of a

160 competitor's pollen tubes could constitute an efficient strategy to bias paternity in polyandrous

161 systems, except perhaps when competing pollen grains come from the same pollen donor (Fig. 2).

162 Yet, negative effects of the number of pollen donors on pollen performance have rarely been 163 reported $[67,68]$, and the molecular basis of any putative antagonistic pollen-pollen interactions is 164 not yet established. In fact, positive effects of greater numbers of pollen grains on pollen 165 performance have often been reported, pointing to the possible role of diffusible molecules in 166 fostering pollen performance and softening pistil tissues (mentoring effect $[69,70]$ ).

168 A major prediction of sexual selection theory is that male-male competition should select for 169 individuals in better 'condition', i.e., those efficient at mating because of their higher genetic 170 qualities [71]. Such 'condition-dependent' sexual selection is expected to be able to purge 171 deleterious mutations at low demographic cost $[39,40]$. Could selection on pollen traits conform to 172 this prediction by reflecting the genetic quality of pollen donors? Investigations of the effect of 173 natural selection acting on pollen suggest that 'condition-dependent' sexual selection may indeed 174 apply to pollen-pistil interactions. Interestingly, enhanced pollen competition and more competitive 
175 pollen traits can lead to improved progeny growth [72,73], and the very success of angiosperms

176 over gymnosperms has even been attributed, in part, to such interactions [74]. While these ideas

177 have been explored specifically in the context of competition among pollen originating from a

178 single plant, they are also relevant to competition among different pollen donors, and empirical

179 results tantalizingly suggest that 'condition-dependent' male-male competition may indeed apply.

181 Scope for female choice during pollen-pistil interactions?

183 There is growing evidence that plants have developed mate-filtering mechanisms in a number of 184 contexts. Genetic incompatibility and other mechanisms of inbreeding or outbreeding avoidance are 185 known to affect pollen donor siring success in the context of different recipients (Table S3). It is 186 clear that plants can reject pollen tubes from closely or distantly related plant genotypes [75,76], or 187 from individuals displaying certain incompatibility alleles [77,78]. These processes may explain 188 why multiple mating generally enhances plant progeny vigor [20]. Such mechanisms of plant mate 189 choice fall into what was recently defined as 'grey zones' of sexual selection, where variation in 190 components of male reproductive success depends on mate identity [79]. But to what extant does 191 mate choice occur among compatible mating based on traits reflecting the performance of 192 prospective mates? Could plants exert inter-sexual female choice in a way that conforms to cryptic 193 female choice, where pollen with certain traits is filtered within the maternal tissues [80]?

195 Female choice may occur through what we might label 'post-pollination mate choice', whereby a 196 bias in paternity with respect to particular pollen traits is brought about by virtue of the morphology 197 or physiology of the maternal plant. Such a manifestation of sexual selection should ultimately be 198 distinguishable from incompatibility and inbreeding or outbreeding avoidance, because the former 
should elicit directional selection for particular pollen traits, while the latter should favour different

200 pollen donors on different recipients.

201

202 It remains questionable whether the envisioned post-pollination mate choice in plants conforms to 203 predictions made by animal-oriented classical models of mate choice (Fig. 3). Both the 'Fisherian 204 runaway' and the 'good-genes' models of sexual selection have focused on how female choice for 205 male attributes may evolve in spite of costs associated with both female preference and male 206 preferred traits [81]. Fisher's [82] 'runaway' theory postulates that females' preferences for male 207 traits should evolve because choosy females ultimately produce progeny with both the sexual 208 preference and the preferred trait. Such models predict evolutionarily stable female preferences 209 driven by a genetic correlation between the preference and the preferred trait when sufficient 210 genetic variance in preferred traits is maintained by deleterious mutations [35] or by spatial 211 variation in selection on the preferred trait [83].

213 It is important to note that 'good-genes' models build on the Fisher's 'runaway' model by assuming 214 that preferred traits are also informative about their bearer's overall genetic quality (Fig. 3; [36,71]), 215 i.e., these models should be seen as two facets of a single theory of female choice [81]. 'Good216 genes' models predict evolutionarily stable female preferences stemming from genetic associations 217 between the male trait and fitness components [36,81]. Initially, 'good-genes' models were 218 criticized because of the absence of erosion of genetic variance in male performance in natural 219 populations subject to female choice [71]. However, it is now accepted that genetic variance in 220 condition-dependent traits may be maintained because the 'condition' is determined by a large 221 number of genes scattered throughout the genome, thus allowing for genetic variation despite low 222 mutation rates [71]. 'Condition-dependent' sexual selection provides the basis for the general 223 prediction that sexual selection should clear mutation loads, a prediction that has received 
224 substantial empirical support in the animal kingdom [84-86]. But could it apply to plants in the

225 context of pollen-pistil interactions?

226

227 There are good reasons to think that models of female choice should apply to plants during the post228 pollination phase. For instance, a pistil trait (e.g., style length) might bias paternity towards certain 229 pollen traits (e.g., fast pollen tube growth), which may become genetically coupled. Pollen traits 230 offer good candidates for a 'good-genes' process, because the pollen performance correlates with 231 various fitness components [10,72,73,87]. In contrast to the male gametes of animals, haploid 232 pollen tubes maintain high gene expression [88], with significant overlap with gene expression at 233 the sporophytic stage [89], potentially rendering pollen traits honest signals of pollen donor's 234 genetic quality. Consistent with the possibility of post-pollination mate choice, a genetic correlation 235 between pollen size and style length was reported in the field mustard (Brassica rapa) [90]. Yet any 236 process of sexual selection operating during pollen-pistil interactions may also bring about sexual 237 conflict [91]. Such conflicts might involve the evolution of female resistance traits in response to 238 fitness costs inflicted by pollen competitive traits, with some peculiarities in hermaphroditic plants 239 (Box 1).

241 The growing awareness of the importance of the post-copulatory component of sexual selection in 242 animals [27] led to an extension of female choice theory to explain the evolution of polyandry 243 [92,93]. 'Sexy-sperm' and 'good-sperm' models predict that genetic correlations between male 244 fertilization success (equivalent to male preferred trait), female polyandry (equivalent to female 245 preference trait), and fitness components can drive the evolution of polyandry [92,93]. Verbal 246 analogies have been made between these models and cases of post-copulatory female traits biasing 247 paternity for certain sperm traits [3] and may therefore have implications for post-pollination mate 
248 choice, too. Yet it seems to us that such situations might apply better to classical models of female

249 choice than to the evolution of polyandry.

250

251 Given the above descriptions, we conjecture that both 'Fisherian runaway' and 'good-genes' 252 processes may apply to pollen-pistil interactions. These models consider, on the one hand, generic 253 processes of the evolution of a costly maternal trait that biases paternity towards a costly paternal 254 trait (Fig. 3), and, on the other hand, genetic correlations that may establish among these traits, as 255 well as between them and other fitness components. Similar to the mechanisms envisioned here, 256 simple genetic correlations between the size of the female copulatory organ and that of sperm has 257 been shown to conform to these models [3]. Sexual selection theory may therefore contribute to 258 understanding the extraordinarily rapid growth of pollen tubes, which ranks among the fastest cell 259 growth known for eukaryotes [94].

\section{Candidate pistil traits for post-pollination mate choice}

263 Biasing the paternity towards pollen donors with specific pollen traits may be achieved by simple 264 pistil traits (Fig. 2; Table S2). The accumulation of more numerous pollen donors could be 265 facilitated by a longer flower opening and larger stigmas while competition among pollen donors 266 could be enhanced by longer styles, decreased expression of molecules that provide nutrition and guidance and, a reduction of space provided to pollen tubes [95]. There have been several reports of 268 reduced style diameter and gradients of nutritive resources [96], which have also been shown to 269 limit the number of pollen tubes that reach the pistil base, leading to 'pollen tube attrition' [97]. 270 Controlling the quantity and quality of the nutritive and guiding molecular matrix can be effected 271 by diminishing molecular excretion through exocytosis and transporter expression, and by 
272 inactivating or deteriorating assisting molecules. Future studies should also establish whether

273 variation in pollen tube signals can manipulate resource provision by pistil tissues.

275 Sexual selection may also target the capacity of pistils to constrain pollen tube growth, thus 276 bringing into competition pollen donors whose pollen landed on stigmas at different times. Stigma 277 receptivity, controlled by stigmatic inhibitors of pollen germination, constitutes the first opportunity 278 for pistils to delay the germination of pollen grains [98]. Further down the path to fertilization, 279 styles can constrain pollen tube kinetics by providing discontinuous nutritive resources, or by 280 delaying the maturation of their basal sections - which typically occurs after flower opening. One 281 extreme version of pistil control in angiosperms is exemplified by obturators, a placental 282 protuberance that regulates access of pollen tubes to the ovary [99]. The switch to a secretory phase 283 of the obturator ensures that only one pollen tube enters the ovary. Pollen recipients that delay 284 access of pollen to the ovary may permit the accumulation of pollen tubes from different pollen 285 donors, allowing selection among pollen genotypes that are particularly efficient at perceiving the 286 molecular switch. The most convincing description of female choice in plants so far concerns post287 zygotic mate choice when embryos compete for accessing maternal resources (Box 2).

\section{Concluding remarks}

291 The scope for sexual selection during pollen-pistil interactions has largely been studied by means of 292 within-generation characterizations of siring patterns. Such approaches, while useful and revealing, 293 fail to disentangle male-male competition from mate choice, not least because the former needs to 294 occur for the latter to be possible [100]. To provide further insights on post-mating sexual selection 295 (see Outstanding Questions), it would be useful to identify pistil traits affecting the siring success 296 hierarchy among pollen donors displaying different pollen traits. Attributing a paternity bias 
297 unambiguously to a female trait can be achieved by comparing paternity on recipient plants

298 displaying variable pistil traits. Testing female choice models further requires quantifying the 299 genetic correlations between the identified pollen and pistil traits. Examining the intra-specific 300 variation of pollen-pistil traits between populations informs on mate choice divergence, while inter301 specific patterns of joint evolution of pollen-pistil traits would allow identifying a non-neutral effect 302 of pistil tissues. Comparing pollen-pistil interactions among closely related species that differ in 303 relevant traits (e.g., outcrossing rates) might help reveal the underlying mechanisms.

305 Applying experimental evolution to vary the opportunity for sexual selection could prove efficient 306 at evaluating the scope for sexual selection, as has been done in numerous studies with animals 307 [84]. Comparing pistil and pollen phenotypes of experimental populations that evolved with 308 monogamy versus polygamy during the post-pollination phase may help to both test predictions of 309 the theory of sexual selection, and to identify new molecules involved in pollen-pistil interactions 310 (Fig. 3). Provided that maternal and paternal traits are involved in paternity bias (determined 311 through paternity analyses), quantitative genetics constitutes a key methodology for testing 312 predictions of female choice models. By favouring the reproduction of high-quality pollen donors 313 through male-male competition or female choice, 'condition-dependent' sexual selection could clear 314 mutation loads [71], with implications for plant conservation and crop management. Future studies 315 should establish whether sexual selection may have positive effects on plant fitness. 


\section{Box 1: Sexual conflict in hermaphroditic plants}

318 Sexual conflicts arise when sexes cannot reach their sex-specific phenotypic optima, owing to

319 antagonistic interactions or genetic correlations with the other sex. Studying sexual selection in

320 hermaphrodites opens yet unresolved questions about sexual conflicts [101]. The particularity of

321 hermaphroditic species is that resource allocation trade-offs may give rise to intersex interactions

322 directly within individuals [102]. Intra-locus sexual conflict (e.g., when the optimum for a

323 phenotypic trait differs between male and female functions) may arise in plants because male and

324 female reproduction rely on the acquisition of different resource types, and on different deployment

325 of such resources. Strategies maximizing donor success can sometimes be detrimental to the gamete

326 recipient, causing inter-locus sexual conflict (e.g., when gamete performance harms the recipient’s

327 reproductive success; [103]). For instance, despite scant investigations on sexual conflict in plants,

328 the evolution of greater pollen competitive abilities in chinese innocence (Collinsia heterophylla)

329 induced female fitness costs to the pollen recipient [61]. A range of sexual conflicts may arise in the

330 context of pollen-pistil interactions. For instance, female fitness may be compromised by the

331 evolution of more competitive pollen tubes that harvest nutritive resources from the pistil or

332 damaging pistil tissues [31]. Alternatively, increased competitive abilities of pollen traits may have

333 evolved as counter-adaptations to female control over mates. The evolution of manipulative traits

334 by male gametophytes could also trigger inter-locus sexual conflicts, e.g., by coercing the diversion

335 of maternal resources for the growth of the ovules they have fertilized at the expense of other

336 maternal fitness components. A male-female genetic conflict may emerge because embryos

337 expressing higher hormonal levels are likely to attract additional maternal resources [103]. In

338 maize, embryos from different paternal genotypes have been shown to compete for maternal

339 resources, with associated costs to female fitness [104]. Accordingly, such inter-locus sexual

340 conflict may favour the evolution of resistance traits (e.g., decreased perception in the embryonic 
341 hormonal signal). Importantly, however, the benefits of purging mutations through sexual selection

342 in animals may be compromised by the disadvantage of sexual conflicts, such as the harassment of 343 females by males [105]. 


\section{Box 2: Some evidence for post-zygotic mate choice in plants}

346 Despite the scant attention so far given to female choice in plants, early studies of plant sexual

347 selection did in fact document some evidence for it. In wild radish, a decrease in plant water 348 provisioning was shown to induce differential seed abortion, favouring the siring success of 349 individuals with pollen tubes able to travel further down the mate's ovary [106]. When water is 350 limiting, plants may abort embryos higher up in the ovary, thus biasing paternity towards pollen 351 donors able to fertilize ovules further down [106]. Such selective seed abortion may lead to non352 random use of pollen in a way consistent with a hypothesis of post-pollination mate choice - though 353 it remains to be shown whether such choice is due to selection under the 'good-genes' or the 354 'runaway’ model. Selective seed abortion may also increase offspring quality [107], but such a 355 result may well be attributable to inbreeding or outbreeding avoidance rather than to directional 356 sexual selection. Paternity analyses performed across the reproductive season in the trumpet wine 357 (Campsis radicans) revealed a consistent decrease in the number of pollen donors throughout the season while controlling for the intensity of pollen competition [108], perhaps suggesting increased selectivity by females over their mates as maternal resources become more and more limiting [108].

360 Similar results were found for some animals in which there is a higher opportunity for post361 copulatory selection with decreasing resources [109]. Studies aimed at distinguishing between the 362 effects of maternal control and competition among embryos on patterns of seed abortion also 363 potentially provide valuable information on the extent to which seed abortion is under the control of 364 pistil tissues. Indeed, cellular and molecular investigations in several plants indicate that embryo 365 abortion may be controlled by degradation of maternal tissues, followed secondarily by degradation 366 of the embryo (e.g., deposition of lignin and cellulose in the integuments; [110]). Viable embryos 367 are commonly aborted by plants, as highlighted by their successful in vitro culture [111]. Together, 
368 these results suggest that maternal plants may indeed exert some control over embryo development, 369 and future research should evaluate its relevance for sexual selection. 
372 Bateman principles: the principles that formalized Darwin’s hypothesis [1] that male reproductive

373 success should depend on access to mating partners more than female reproductive success, a 374 disparity ultimately rooted in anisogamy [16]. Bateman principles decompose into three predictions: 375 variance in (1) reproductive and (2) mating success should be larger in the sex that produces greater 376 numbers of smaller gametes (generally males), and (3) this sex should show a steeper relationship 377 between reproductive success (i.e., number of offspring) and mating success (i.e., the number of 378 sexual partners) than the sex producing large and less numerous gametes [16].

379 Cryptic female choice: inter-sexual selection driven by female mechanisms resulting in biased 380 sperm use and altering the male paternity share [80].

Experimental evolution: study of evolutionary responses to experimental conditions of independent experimental populations.

Intra-sexual competition for mates and/or their gametes: competition within one sex (typically males) for access to sexual partners (i.e., reach a pistil mate) and/or their gametes (ovules).

Inter-sexual female choice: female choice involves a female trait inducing a bias in paternity for males displaying particular traits (e.g., displays, pollen traits, incompatibility alleles); in this review, we particularly focus on female choice eliciting directional selection for a particular male pollen trait.

Post-pollination mate choice: paternity bias favouring pollen donors that display specific pollen or pollen tube trait(s) elicited by a pistil morphological or molecular trait.

Post-zygotic mate choice: maternally controlled variance in resource allocation to embryos causing paternity bias and favouring pollen donors that display particular trait(s); such embryo abortion may be the consequence of varying resource allocation to different fruits or different embryos within 394 fruits. 
395 Sexual conflict: sexual conflict arises when a trait beneficial for the fitness of one sex is detrimental 396 to that of the other. Sexual conflict may involve a single locus when its optimum expression differ 397 between sexes, or several loci when the mating performance of one sex compromises the fitness of 398 the other sex.

399 Sexual selection: 'differences in reproduction that arise from variation among individuals in traits 400 that affect success in competition over mates and fertilizations' (as defined by [112], but see [79] for 401 a review of various alternative definitions). 


\section{Figure legends:}

403 Figure 1: Examples of potentially sexually selected plant traits. Field mustard plants (Brassica

404 rapa) (a.) pollinated during nine generations by bumblebees were taller, produced more scent and 405 changed their ultraviolet reflection compared to plants pollinated by hoverflies pointing to a rapid 406 evolution of traits involved in pollen export ([23] courtesy of Florian Schiestl). In the dioecious 407 white campion (Silene latifolia) (b.), differences in male flower sizes induced through artificial 408 selection led to an earlier flower phenology in the 'small-flower' line which better matched female 409 phenology, thus offering greater mating opportunities to males from the 'small-flower' compared to 410 the 'large-flower' lines ([24] courtesy of Lynda Delph). Dispersal structures containing pollen 411 grains, called pollinaria (c.), evolved 'horns' in various milkweed species which decrease the 412 pollination success of rival pollen donors by preventing the attachment of a subsequent pollinarium 413 ([25] courtesy of Andrea Cocucci). Pollen morphology (d.), including their size and spine density, 414 affects the probability of attachment on pollinator's bodies [26] (pollen of Catananche caerulea, 415 courtesy of Agnès Mignot, ISEM reference palynological database). Male plant architecture of the 416 wind-pollinated annual mercury (Mercurialis annua) (e.), including longer branch size and longer 417 peduncles of male-flower bearing inflorescences, was shown to enhance pollen dispersal to a 418 greater number of mates [18,21]. Pollen-pistil interactions during compatible matings offers several 419 candidate mechanisms for the operation of both intra-sexual competition for fertilization, and inter420 sexual mate choice that may conform to the theory of sexual selection (image of pollen germinating 421 on a Solanum lycopersicum pistil by J-C. Mollet).

423 Figure 2: Pollen success after arrival on the stigma depends on successive male-female 424 interactions providing as many opportunities for sexual selection. Intra-sexual competition 425 among pollen donors may increase variance in paternity via the expression of pollen traits: pollen 426 from different donors may express different abilities to adhere to a dry pistil stigmatic surface (1); 
427 to re-hydrate pollen (2); to produce a pollen tube and grow down the stigmatic tissue and the style

428 (3); to monopolize pistilar nutritive resources and perceive cues guiding pollen towards the ovule 429 through the style (4); to penetrate an unfertilized ovule following pistilar guidance, mostly exerted

430 by haploid female gametophyte within the ovary (5); to achieve double fertilization (6); and to 431 ensure resource provisioning to developing seeds (7). Male-male competition may ultimately bring 432 about negative pollen-pollen interactions provided that such interactions can occur. Inter-sexual 433 post-pollination mate choice may also bias paternity as a result of the evolution of simple pistil 434 traits at all steps in the course of pollen-pistil interactions: larger stigmatic surfaces and flowers 435 opened for longer periods may enhanced the number of pollen competitors; longer styles or 436 decreased expression of pollen-tube assisting molecules may select for the most efficient pollen 437 tubes; pistil control over pollen tube growth may select for the pollen tubes most capable of 438 perceiving the ovary guidance signal; and pistil tissues may direct resource to certain developing 439 embryos (Box 2). Pollen-pistil interactions may conform to classical models of the theory of sexual 440 selection, modeling intra-sexual competition and inter-sexual mate choice.

442 Figure 3: Research agenda for testing models of female choice during pollen-pistil interactions

443 in angiosperms. The 'runaway' model predicts an evolutionarily stable female preference because 444 females expressing a preference for a preferred male trait produce more attractive progeny with 445 correspondingly greater access to mates. This preference for attractive males results in a genetic 446 correlation between the preference and preferred trait. 'Good-genes' models add to the runaway 447 model a fitness component shared by both sexes, and predict evolutionarily stable female choice 448 because females expressing a preference produce progeny with greater fitness, besides their greater 449 access to sexual partners; i.e., because the preferred trait is a good indicator of male quality. The 450 negative genetic correlation found between sperm length and spermatheca size in the taurus scarab, 451 a trait known to bias paternity for males of smaller sizes provided an example of a post-copulatory 
452 female choice [3]. We propose a research agenda for testing whether putative post-pollination mate 453 choice may conform to these predictions: experimental evolution may allow identifying whether 454 several generations of evolution of enforced monogamy (where no competition or mate choice can 455 occur) versus polygamy during the post-pollination phase (through hand-pollination) can elicit the 456 evolution of pollen and pistil traits; paternity analyses further allows determining whether evolved 457 pollen and pistil traits can be considered as preferred and preference traits because evolved pistil 458 traits cause paternity bias for evolved pollen traits; finally, quantitative genetics allows tests for 459 established genetic correlations between pollen, pistil and fitness traits, conforming to 'runaway' 460 and 'good-genes' models. 


\section{Acknowledgments}

462 J.T. was funded by a Marie Skłodowska-Curie grant (\#844321). AL and JCM were funded by the 463 University of Rouen Normandy and the French Ministry of Research and Higher Education. T.J. 464 was funded by the Centre national de la recherche scientifique (CNRS) and the German Research 465 Foundation (DFG grant number: JA 2653/2-1). 


\section{References}

467 1. Darwin, C., eds. (1871) The descent of man and selection in relation to sex. Vol. 1, Murray.

2. Grant, V. (1995) Sexual selection in plants: pros and cons. Proc. Natl. Acad. Sci. U. S. A. 92, $1247-1250$.

3. Simmons, L.W. and Kotiaho, J.S. (2007) Quantitative genetic correlation between trait and preference supports a sexually selected sperm process in the beetle Onthophagus taurus. Proc. Natl. Acad. Sci. U. S. A. 104, 16604-16608.

4. Hoffer, J.N. et al. (2017) Sexual selection gradients change over time in a simultaneous

5. Patlar, B. et al. (2020) Seminal fluid-mediated manipulation of post-mating behavior in a simultaneous hermaphrodite. Curr. Biol. 30, 143-149.

6. Morimoto, J. et al. (2019) Sex peptide receptor-regulated polyandry modulates the balance of pre- and post-copulatory sexual selection in Drosophila. Nat. Commun. 10, 1-12.

7. Willson, M.F. (1994) Sexual selection in plants: perspective and overview. Am. Nat. 144, S13S39.

8. Arnold, S.J. (1994) Bateman's principles and the measurement of sexual selection in plants and animals. Am. Nat. 144, S126-S149.

9. Delph, L.F. and Havens, K. (1998) Pollen competition in flowering plants. In Sperm competition and sexual selection (pp. 149-173). Academic Press.

10. Skogsmyr, I. and Lankinen, Å. (2000) Potential selection for female choice in Viola tricolor. Evol. Eco. Res. 2, 965-979.

11. Bernasconi, G. et al. (2004) Evolutionary ecology of the prezygotic stage. Science 303, 971975. 
490 13. Cutter, A.D. (2019) Reproductive transitions in plants and animals: selfing syndrome, sexual 491 selection and speciation. New Phytol. 224, 1080-1094.

492 14. Arnold, S. (1994) Bateman's principles and the measurement of sexual selection in plants and 493 animals. Am. Nat. 144, S126-S149.

494 15. Morgan, M.T. (1994) Models of sexual selection in hermaphrodites, especially plants. Am. Nat. 144 S100-S125.

16. Bateman, A.J. (1948) Intra-sexual selection in Drosophila. Heredity 2, 349-368.

17. Johnson, M.G. and Shaw, A.J. (2016) The effects of quantitative fecundity in the haploid stage on reproductive success and diploid fitness in the aquatic peat moss Sphagnum macrophyllum. Heredity 116, 523-530.

18. Tonnabel, J. et al. (2019) Do metrics of sexual selection conform to Bateman's principles in a wind-pollinated plant? Proc. Biol. Sci. 286, 20190532.

19. Michalski, S.G. and Durka, W. (2009) Pollination mode and life form strongly affect the relation between mating system and pollen to ovule ratios. New Phytol. 183, 470-479.

20. Pannell, J.R. and Labouche, A.M. (2013) The incidence and selection of multiple mating in plants. Phil. Trans. Biol. Sci. 368, 20120051.

21. Tonnabel, J. et al. (2019) Sex specific selection on plant architecture through "budget” and “direct” effects in experimental populations of the wind pollinated herb, Mercurialis annua.

22. Schoen, D.J. and Stewart, S.C. (1986) Variation in male reproductive investment and male Evolution 73, 897-912. reproductive success in white spruce. Evolution 40, 1109-1120.

23. Gervasi, D.D. and Schiestl, F.P. (2017) Real-time divergent evolution in plants driven by pollinators. Nat. Commun. 14, 14691.

513 24. Delph, L.F. and Herlihy, C.R. (2012) Sexual, fecundity, and viability selection on flower size and number in a sexually dimorphic plant. Evolution 66, 1154-1166. 
515 25. Coccuci, A.A. et al. (2014) The buck in the milkweed: evidence of male-male interference among pollinaria on pollinator. New Phytol. 203, 280-286.

26. Lynn, A. et al. (2020). Sexual and natural selection on pollen morphology in Taraxacum. Am. J. Bot. 107, 364-374.

27. Birkhead, T.R. (2010). How stupid not to have thought of that: post copulatory sexual selection. J. Zool. 281, 78-93.

28. Snow, A.A. and Spira, T.P. (1991) Differential pollen-tube growth rates and nonrandom fertilization in Hibiscus moscheutos (Malvaceae). Am. J. Bot. 78, 1419-1426.

29. Bennett, J.M. et al. (2018) GloPL, a global data base on pollen limitation of plant reproduction. Sci. Data 5, 180249.

36. Iwasa, Y. et al. (1991) The evolution of costly mate preferences II. The "handicap" principle. 
37. Parker, G.A. (1990) Sperm competition games: raffles and roles. Proc. Biol. Sci. 242, 120-126.

38. Agrawal, A.F. (2001) Sexual selection and the maintenance of sexual reproduction. Nature 411, 692-695.

39. Siller, S. (2001) Sexual selection and the maintenance of sex. Nature 411, 689-692.

40. Haldane, J.B.S. (1924) A mathematical theory of natural and artificial selection, part I. Proc. Camb. Phil. Soc. 23, 19-41.

41. Fisher, R.A. (1941) Average excess and average effect of a gene substitution. Ann. Eugen. 11, 53-63.

42. Wright, S. (1951) The genetical structure of populations. Ann. Eugen. 15, 323-354.

43. Durand, E. et al. (2014) Dominance hierarchy arising from the evolution of a complex small RNA regulatory network. Science 346, 1200-1205.

44. Brom, T. et al. (2020) Breakdown of gametophytic self incompatibility in subdivided populations. Evolution 74, 270-282.

45. Tiffin, P. et al. (2001) Asymmetrical crossing barriers in angiosperms. Proc. Biol. Sci. 268, 861867.

46. Brandvain, Y. and Haig, D. (2005) Divergent mating systems and parental conflict as a barrier to hybridization in flowering plants. Am. Nat. 166, 330-338.

47. Tung, C. W. et al. (2005) Genome-wide identification of genes expressed in Arabidopsis pistils specifically along the path of pollen tube growth. Plant Physiol. 138, 977-989.

48. Iwano, M. et al. (2014) A pollen coat-inducible autoinhibited Ca2+-ATPase expressed in stigmatic papilla cells is required for compatible pollination in the Brassicaceae. Plant Cell 26, 636-649.

49. Chae, K. and Lord, E.M. (2011) Pollen tube growth and guidance: roles of small, secreted proteins. Ann. Bot. 108, 627-636. 
564 50. Palanivelu, R. and Tsukamoto, T. (2012) Pathfinding in angiosperm reproduction: pollen tube guidance by pistils ensures successful double fertilization. WIREs Dev. Biol. 1, 96-113.

566 51. Mizukami, A.G. et al. (2016) The AMOR arabinogalactan sugar chain induces pollen-tube competency to respond to ovular guidance. Curr. Biol. 26, 1091-1097.

52. Chen, Y. et al. (2014) Transcriptome analysis of the Arabidopsis semi-in vivo pollen tube guidance system uncovers a distinct gene expression profile. J. Plant Biol. 57, 93-105.

53. Higashiyama, T. and Hamamura, Y. (2008) Gametophytic pollen tube guidance. Sex. Plant Repro. 21, 17-26.

572 54. Mizuta, Y. and Higashiyama, T. (2018) Chemical signaling for pollen tube guidance at a glance. J. Cell Sci. 131.

55. Higashiyama, T. et al. (2001) Pollen tube attraction by the synergid cell. Science 293, 14801483.

576 56. Völz, R. et al. (2013) Ethylene signaling is required for synergid degeneration and the establishment of a pollen tube block. Dev. Cell 25, 310-316.

57. Leydon, A.R. et al. (2015) Pollen tube discharge completes the process of synergid degeneration that is initiated by pollen tube-synergid interaction in Arabidopsis. Plant Physiol. 169, 485496.

58. Sarkissian, T.S. and Harder, L.D. (2001) Direct and indirect responses to selection on pollen size in Brassica rapa L. J. Evol. Biol. 14, 456-468.

59. Lamborn, E. et al. (2005) The potential for adaptive evolution of pollen grain size in Mimulus guttatus. New Phytol. 167, 289-296.

60. Lankinen, Å. et al. (2009) Pollen-tube growth rates in Collinsia heterophylla (Plantaginaceae): one-donor crosses reveal heritability but no effect on sporophytic-offspring fitness. Ann. Bot. 103, 941-950. 
61. Lankinen, Å. et al. (2017) Sexually antagonistic evolution caused by male-male competition in the pistil. Evolution 71, 2359-2369.

62. Chen, J. et al. (2015) Down-regulating CsHT1, a cucumber pollen-specific hexose transporter, inhibits pollen germination, tube growth, and seed development. Plant Physiol. 168, 635647.

63. Zhang, G.Y. et al. (2010) BoPMEI1, a pollen-specific pectin methylesterase inhibitor, has an essential role in pollen tube growth. Planta 231, 1323-1334.

64. Hao, L. et al. (2016) AtVPS41-mediated endocytic pathway is essential for pollen tube-stigma interaction in Arabidopsis. Proc. Natl. Acad. Sci. U. S. A. 113, 6307-6312.

65. Mollet, J.C. et al. (2013) Cell wall composition, biosynthesis and remodeling during pollen tube growth. Plants 2, 107-147.

66. Yanagisawa, N. et al. (2017) Capability of tip-growing plant cells to penetrate into extremely narrow gaps. Sci. Rep. 7, 1403.

67. Swanson, R.J. et al. (2016) Pollen performance traits reveal prezygotic nonrandom mating and interference competition in Arabidopsis thaliana. Am. J. Bot. 103, 498-513.

68. Cruzan, M.B. (1990) Variation in pollen size, fertilization ability, and postfertilization siring ability in Erythronium grandiflorum. Evolution 44, 843-856.

69. Gaget, M. et al. (1989) The mentor pollen phenomenon in poplars: a new concept. Theor. Appl. Genet. 78, 129-135.

70. Vogler, F. et al. (2014). Brassinosteroids promote Arabidopsis pollen germination and growth. Plant Reprod. 27, 153-167.

71. Rowe, L. and Houle, D. (1996) The lek paradox and the capture of genetic variance by condition dependent traits. Proc. Biol. Sci. 263, 1415-1421.

72. Mulcahy, D.L. and Mulcahy, G.B. (1975) The influence of gametophytic competition on sporophytic quality in Dianthus chinensis. Theor. Appl. Genet. 46, 277-280. 
613 73. Ottaviano, E. et al. (1988) Pollen competitive ability in maize: within population variability and response to selection. Theor. Appl. Genet. 76, 601-608.

615 74. Mulcahy, D.L. (1979) The rise of angiosperms: a genecological factor. Science 206, 20-23.

616 75. Doucet, J. et al. (2016) Pollen acceptance or rejection: a tale of two pathways. Trends Plant Sci. 21, 1058-1067.

618 76. Waser, N.M. and Price, M.V. (1994) Crossing-distance effects in Delphinium nelsonii 619

77. Genete, M. et al. (2020) Genotyping and de novo discovery of allelic variants at the Brassicaceae self-incompatibility locus from short-read sequencing data. Mol. Biol. Evol. 37 1193-1201.

78. Guo, H. et al. (2019) Mate selection in self-compatible wild tobacco results from coordinated variation in homologous self-incompatibility genes. Curr. Biol. 29, 2020-2030.

79. Alonzo, S.H. and Servedio, M.R. (2019) Grey zones of sexual selection: why is finding a modern definition so hard? Proc. Biol. Sci. 286, 20191325.

80. Firman, R.C. et al. (2017) Postmating female control: 20 years of cryptic female choice. Trends Ecol. Evol. 32, 368-382.

81. Kokko, H. et al. (2006) Unifying and testing models of sexual selection. Annu. Rev. Ecol. Evol. Syst. 37, 43-66.

82. Fisher, R.A., eds. (1930) The Genetical Theory of Natural Selection, Clarendon, Oxford.

83. Day, T. (2000) Sexual selection and the evolution of costly female preferences: spatial effects. Evolution 54, 715-730.

634 84. Cally, J.G. et al. (2019) Meta-analytic evidence that sexual selection improves population 635 fitness. Nat. Commun. 10, 1-10.

636 85. Noël, E. et al. (2019) Sexual selection and inbreeding: two efficient ways to limit the accumulation of deleterious mutations. Evol. Lett. 3, 80-92. 
638 86. Baur, J., and Berger, D. (2020) Experimental evidence for effects of sexual selection on condition-dependent mutation rates. Nat. Ecol. Evol. 4, 737-744.

640

641

642

643

87. Madjidian, J.A. et al. (2020) Direct and indirect selection on mate choice during pollen competition: Effects of male and female sexual traits on offspring performance following two donor crosses. J. Evol. Biol. 33, 1452-1467.

88. Ishka, M.R. et al. (2018) A comparison of heat-stress transcriptome changes between wild-type Arabidopsis pollen and a heat-sensitive mutant harboring a knockout of cyclic nucleotidegated cation channel 16 (cngc16). BMC Genom. 19, 549.

89. Honys, D. and Twell, D. (2003) Comparative analysis of the Arabidopsis pollen transcriptome. Plant Physiol. 132, 640-652.

90. Sarkissian, T.S. and Harder, L.D. (2001) Direct and indirect responses to selection on pollen size in Brassica rapa L. J. Evol. Biol. 14, 456-468.

91. Kokko, H. and Jennions, M.D. (2014) The relationship between sexual selection and sexual conflict. Cold Spring Harb. Perspect. Biol. 6, a017517.

92. Yasui, Y. (1997). A" good-sperm" model can explain the evolution of costly multiple mating by females. Am. Nat. 149, 573-584.

93. Bocedi, G. and Reid, J.M. (2015) Evolution of female multiple mating: A quantitative model of the “sexually selected sperm” hypothesis. Evolution 69, 39-58.

94. Dehors, J. et al. (2019). Evolution of cell wall polymers in tip-growing land plant gametophytes: composition, distribution, functional aspects and their remodeling. Front. Plant Sci. 10, 441.

95. Marshall, D.L. and Folsom, M.W. (1991) Mate choice in plants: an anatomical to population perspective. Annu. Rev. Ecol. Syst. 22, 37-63.

96. Cruzan, M.B. (1986) Pollen tube distributions in Nicotiana glauca: evidence for density dependent growth. Am. J. Bot. 73, 902-907. 
663 97. Hormaza, J.I. and Herrero, M. (1996) Dynamics of pollen tube growth under different 664 competition regimes. Sex. Plant Reprod. 9, 153-160.

665 98. Okamoto, G. et al. (1995) Pollen tube growth inhibitors from Pione grape pistils. Am. Jour. Eno. Viti. 46, 17-21.

99. Losada, J.M. and Herrero, M. (2017) Pollen tube access to the ovule is mediated by glycoprotein secretion on the obturator of apple (Malus× domestica, Borkh). Ann. Bot. 119, 989-1000.

100. Stanton, M.L. (1994) Male-male competition during pollination in plant populations. Am. Nat. 144, S40-S68.

672 101. Schärer, L. et al. (2015) Sexual conflict in hermaphrodites. Perspec. Biol. 7, a01673.

673 102. Abbott, J.K. (2011) Intra-locus sexual conflict and sexually antagonistic genetic variation in 674 hermaphroditic animals. Proc. Biol. Sci. 278, 161-169.

675 103. Mogensen, H.L. (1985) Ultracytochemical localization of plasma-membrane-associated phosphatase activity in developing tobaccoseeds. Am. J. Bot. 72, 741-754.

104. Cailleau, A. et al. (2018) Dividing a maternal pie among half-sibs: Genetic conflicts and the control of resource allocation to seeds in maize. Am. Nat. 192, 577-592.

679 105. Yun, L. et al. (2018) Competition for mates and the improvement of nonsexual fitness. Proc. Natl. Acad. Sci. U. S. A. 115, 6762-6767.

681 106. Marshall, D.L. and Ellstrand, N.C. (1988) Effective mate choice in wild radish: evidence for selective seed abortion and its mechanism. Am. Nat. 131, 736-759.

683 107. Stephenson, A.G. and Winsor, J.A. (1986) Lotus corniculatus regulates offspring quality through selective fruit abortion. Evolution 40, 453-458.

685 108. Bertin, R.I. (1985) Nonrandom fruit production in Campsis radicans: between-year 686 consistency and effects of prior pollination. Am. Nat. 126, 750-759. 
687 109. Janicke, T. et al. (2015) Environment-dependent sexual selection: Bateman's parameters 688 under varying levels of food availability. Am. Nat. 185, 756-768.

689 110. Pimienta, E. and Polito, V.S. (1982) Ovule abortion in 'nonpareil' almond (Prunus dulcis 690 [Mill.] DA Webb). Am. J. Bot. 69, 913-920.

691 111. Nakamura, Y. (1988) Efficient differentiation of adventitious embryos from cotyledon culture 692 of Camellia sinensis and other Camellia species. Chag. Kenk. Hoko. 67, 1-12.

693 112. Andersson, M. (1994). Sexual selection (Vol. 72). Princeton University Press. 


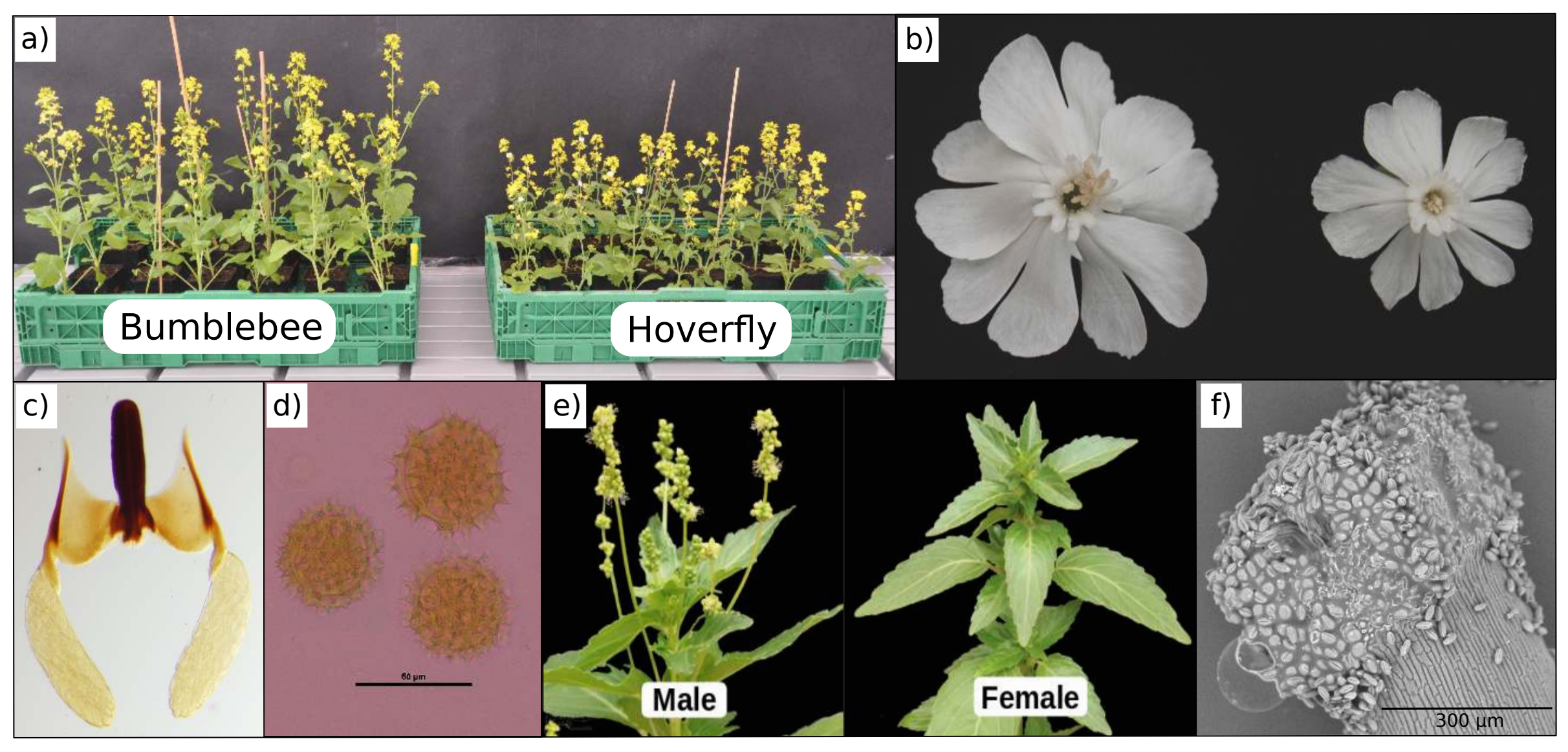

Figure 1 
Opportunities for sexual selection during pollen-pistil interactions

\section{Hypothetical source of variance in paternity}

Male function

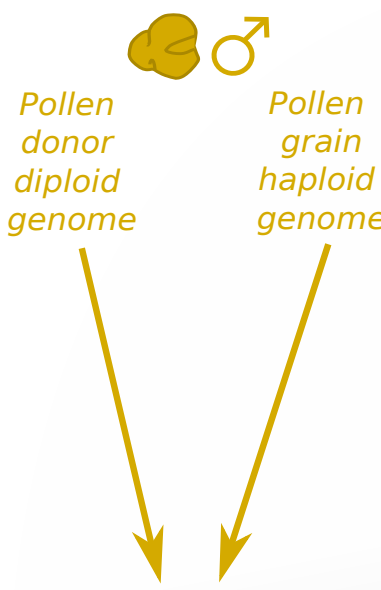

Pollen traits (morphologica) cytological

EVOLUTIONARY BIOLOGY

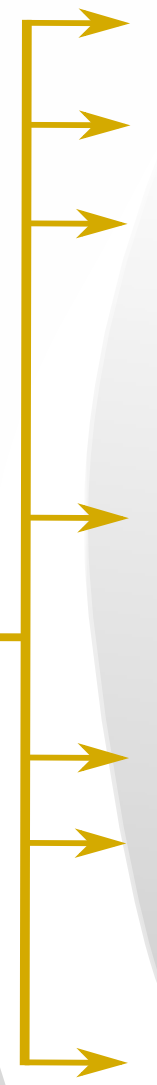

Pollen growth in style 4 Pollen germination and growth in stigma

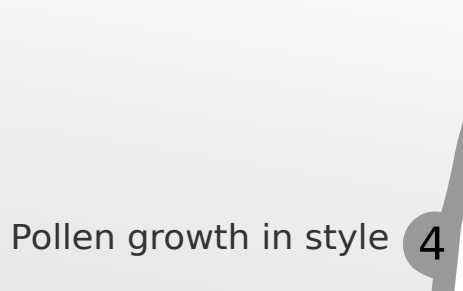

Ovule penetration Fertilisation Zygotic diploid genome Zygotic traits

Seed development 7

Male reproductive success

MOLECULAR BIOLOGY
Hypothetical source of variance in paternity

Female function

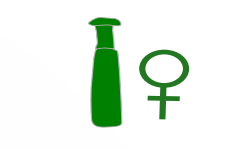

Pollen recipient diploid genome

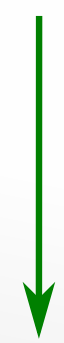

Pistil traits morphological, cytological molecular)$$
\text { . }
$$

$$
\text { BIOLOGY }
$$

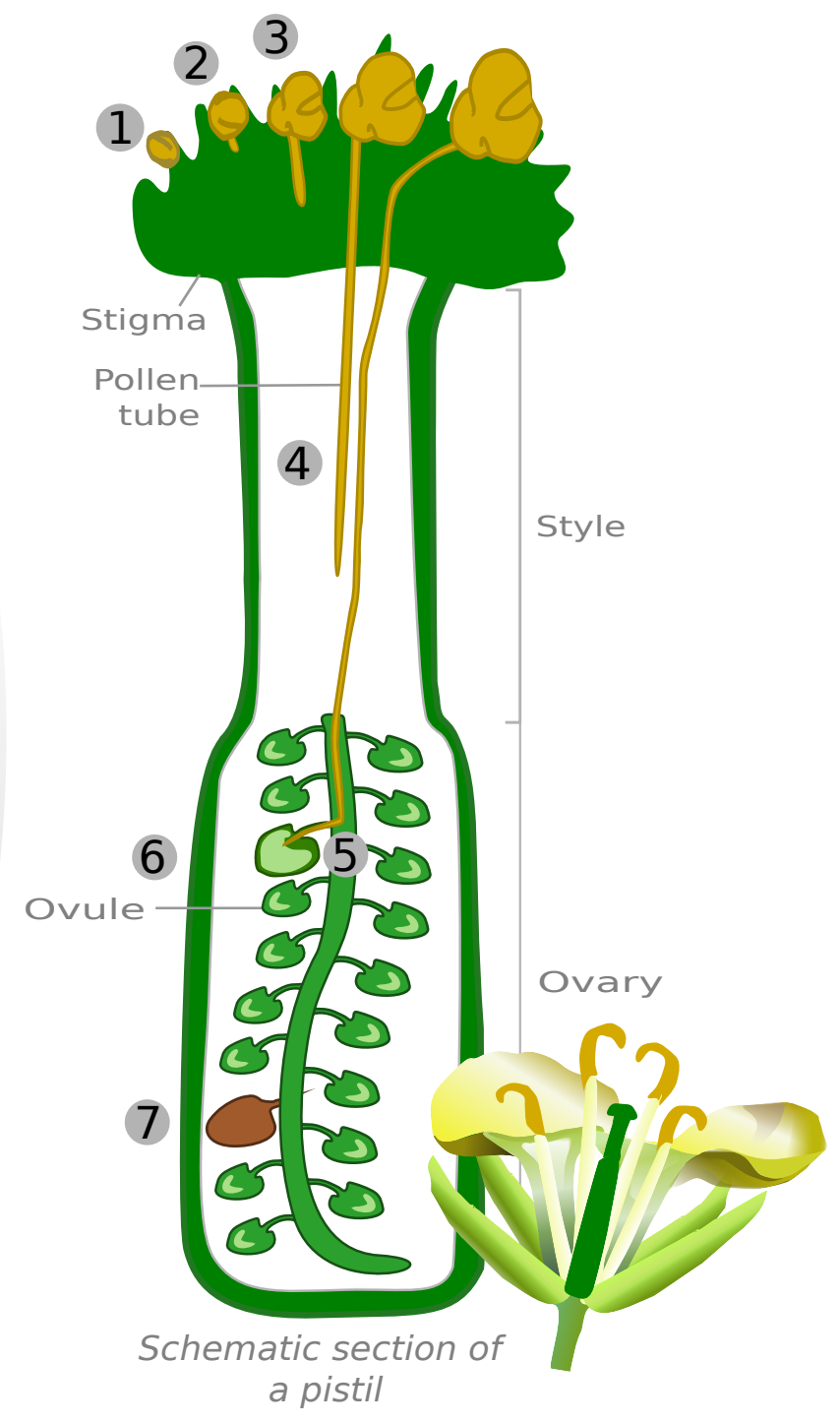

Figure 2 
MODELS PREDICTING FEMALE CHOICE
Testing

predictions

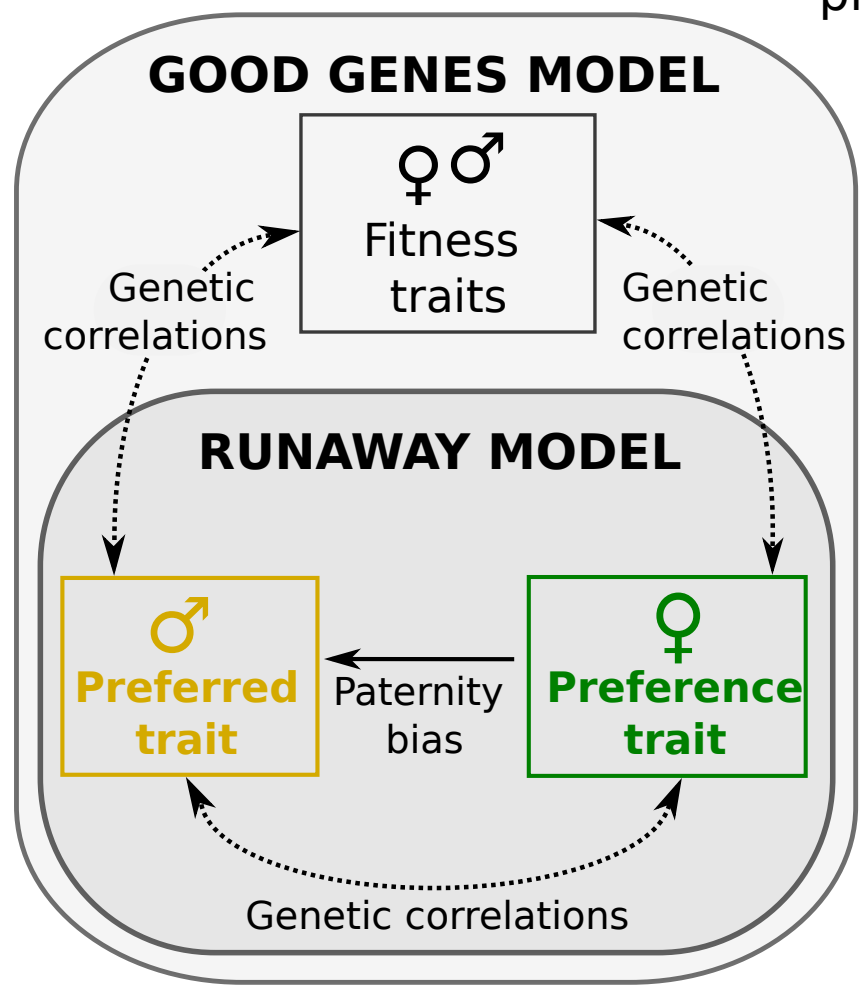

$\longrightarrow$ RESEARCH AGENDA

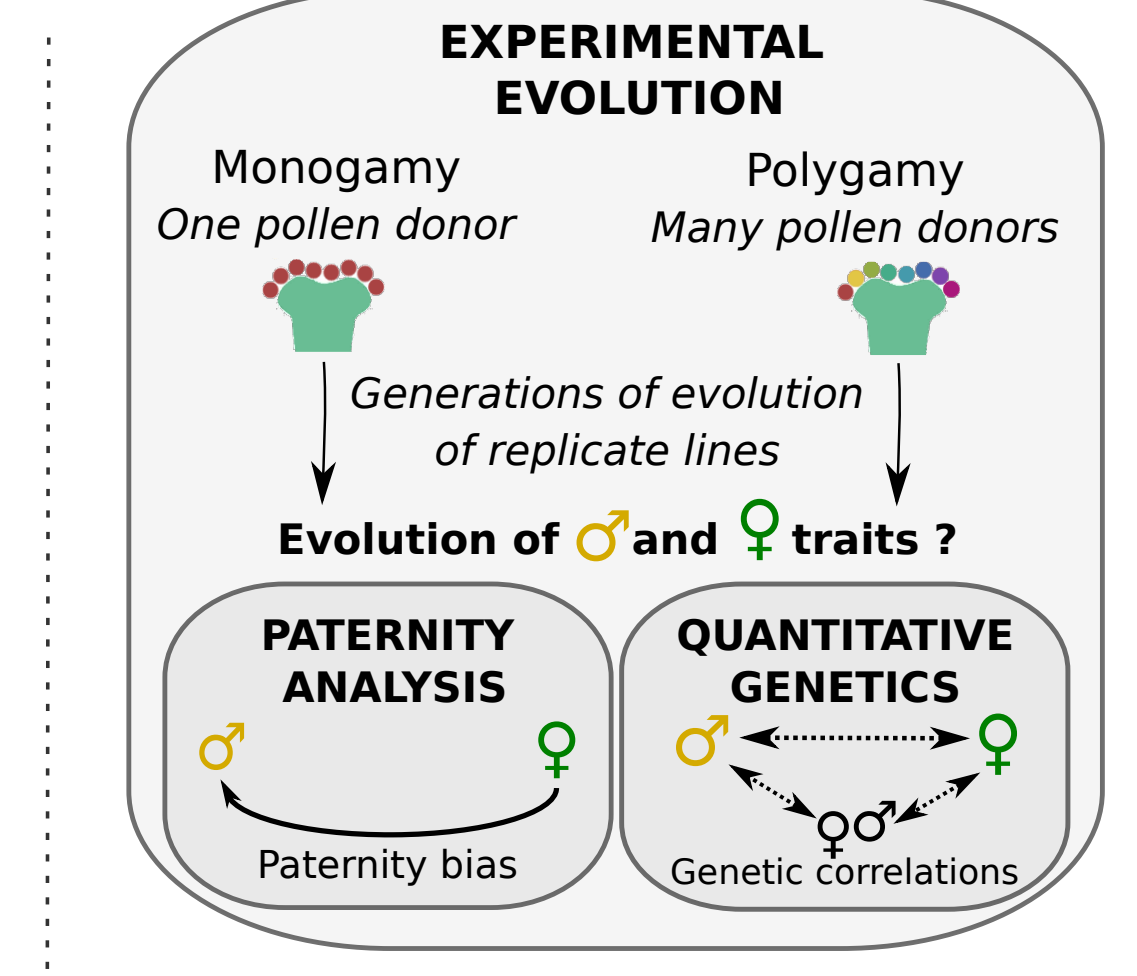

Figure 3 


\section{Supplementary Material}

The scope for post-mating sexual selection in plants

Jeanne Tonnabel $^{1 *}$, Patrice David ${ }^{1}$, Tim Janicke ${ }^{1}$, Arnaud Lehner ${ }^{2}$, Jean-Claude Mollet ${ }^{2}$, John Pannell ${ }^{3}$, Mathilde Dufaÿ ${ }^{1}$

${ }^{1}$ Centre d’Ecologie Fonctionnelle et Evolutive (CEFE), UMR 5175, CNRS, Université de Montpellier, Université Paul Valéry Montpellier, EPHE, 1919 route de Mende, 34293 Montpellier Cedex 5, France

${ }^{2}$ Normandie Univ, UNIROUEN, Laboratoire Glycobiologie et Matrice Extracellulaire Végétale (GlycoMEV), SFR 4377 NORVEGE, IRIB, Carnot I2C, 76000 Rouen, France

${ }^{3}$ Department of Ecology and Evolution, University of Lausanne, 1015 Lausanne, Switzerland

Corresponding author: Jeanne Tonnabel (jeanne.tonnabel@cefe.cnrs.fr) 
Table S1 Summary of the studies investigating the possibility of male-male competition occurring in the post-pollination phase

\section{Methodology}

Comparison of seed siring success after mixed donor hand-pollination

Comparison of pollen tube growth rates of two pollen donors in hand-pollinations on two pistil ramification and estimation of siring success through paternity analyses

In vivo and in vitro pollen tube growth rate assessment and estimation of seed siring success following twodonor hand-pollinations

Comparison of within fruit paternity by different pollen donor in maternal stressed and non-stressed plants

Comparison of seed siring success of different pollen donors with different $\mathrm{S}$-alleles than the pollen recipient

Comparison of seed siring success of self and outcrossed pollen donors in relation with their pollen tube growth

Comparison of seed siring success after two-donor pollination; artificial selection on seed siring success

Comparison of seed siring success after mixed pollinations among pollen donors with high versus low selfing history

Comparison of seed siring success after controlled pollination with varying quantity of fertile pollen

Comparison of fertilization ability and post-fertilization ability of pollen from different donors following mixed pollination

\section{Main result testing for male-male competition}

Positive correlation between pollen donor seed siring success and pollen tube growth rate and number of pollen tubes reaching different section of the style

Positive correlation between pollen donor seed siring success and pollen tube growth rate

Significant variation among pollen donors in pollen tube growth rate which was positively correlated to the seed siring ability following mixed pollen donor pollination

Pollen donor variation in abilities to sire seeds at different depth within the maternal ovary leading to variance in seed size between pollen donors because of a gradient of increasing seed size with ovary depth.

Significant variation in seed siring success among pollen donors but which was not related to pollen performances perhaps because the latter was measured in single pollen donor crosses thus excluding pollen-pollen interactions

Significant variation in seed siring success among pollen donors but that was not related to pollen performances perhaps because the latter were measured in single pollen donor crosses thus excluding the pollen-pollen interactions

Pollen tube growth rate had a strong effect on seed siring success, which, led to an increased seed production by offspring. Artificial selection of offspring sired by superior pollen donors also resulted in reduced variation in seed production and pollen tube growth rate.

\section{Reference and} species

[S1] Prunus avium

[S2] Hibiscus

moscheutos

[S3] Betula pendula

[S4] Raphanus sativus

[S5] Raphanus sativus

[S6] Echium vulgare

Significant among pollen donors variation in seed siring success which was not determined by the selfing history of pollen donors; but, pollen donors producing smaller pollen grains did sire more seeds.

Significant variation in paternal success between pollen donors; pollen size was positively related to faster pollen tube growth rates and greater paternal success in one of the two orchads studied.

[S8] Pseudotsuga

menziesii

[S9] Pseudotsuga

menziesii

Seed siring ability was positively correlated with pollen size and larger seed abortion for ovules [S10] Erythronium sired by a second pollen donor was found when the first pollen donor showed large pollen size. grandiflorum 
Table S2 Main candidate molecules produced by different sections of pistil tissues reported to be involved in the pollen-pistil molecular interactions, which may be involved in sexual selection for a putative mate choice process.

\begin{tabular}{|c|c|c|c|c|}
\hline Localization & Molecule & Type of molecule & $\begin{array}{l}\text { Putative function to support to } \\
\text { microgametophytes }\end{array}$ & Some references \\
\hline Stigma & $\begin{array}{l}\text { S-locus Receptor Kinase } \\
\text { (SRK), S-locus Glycoprotein } \\
\text { (SLG) }\end{array}$ & Protein, Glycoprotein & $\begin{array}{l}\text { Female determinants in sporophytic self-incompatibility in } \\
\text { Brassicaceae }\end{array}$ & {$[\mathrm{S} 12, \mathrm{~S} 13]$} \\
\hline Stigma & Expansins & Protein & Cell wall remodeling facilitating pollen tube penetration & {$[\mathrm{S} 14, \mathrm{~S} 15]$} \\
\hline Stigma & $\begin{array}{l}\text { Lipid transfer protein } \\
\text { (Tobacco LTP2) }\end{array}$ & Protein & Facilitating pollen tube growth and cell wall loosening & [S16] \\
\hline Stigma & $\begin{array}{l}\text { Phytocyanin (Chemocyanins, } \\
\text { Plantacyanins) }\end{array}$ & Protein & Pollen tube guidance and growth & {$[\mathrm{S} 17, \mathrm{~S} 18]$} \\
\hline$\overline{\text { Stigma }}$ & Calcium & Mineral & $\begin{array}{l}\text { Spikes of calcium after adhesion, hydration and pollen } \\
\text { germination within the papilla cell wall }\end{array}$ & [S19] \\
\hline Stigma & $\mathrm{H} 2 \mathrm{O} 2$ & $\begin{array}{l}\text { Reactive Oxygen } \\
\text { Species (ROS) }\end{array}$ & $\begin{array}{l}\text { Accumulation in the stigma and decrease upon pollination } \\
\text { concomitantly with NO production by the pollen: stigma- } \\
\text { pollen interaction }\end{array}$ & {$[\mathrm{S} 20, \mathrm{~S} 21, \mathrm{~S} 22, \mathrm{~S} 23]$} \\
\hline $\begin{array}{l}\text { Stigma } \\
\text { Style }\end{array}$ & S-RNases & Glycoprotein & $\begin{array}{l}\text { Female determinant in gamatophytic Self-Incompatibility } \\
\text { in Solanaceae }\end{array}$ & [S24] \\
\hline $\begin{array}{l}\text { Stigma } \\
\text { Style }\end{array}$ & PrsS, 14kDa & Protein & $\begin{array}{l}\text { Female determinant in gamatophytic Self-Incompatibility } \\
\text { in Papaver rhoeas }\end{array}$ & [S25] \\
\hline $\begin{array}{l}\text { Stigma } \\
\text { Style }\end{array}$ & $\begin{array}{l}\text { Cell wall remodeling } \\
\text { enzymes and Glycoside } \\
\text { hydrolases }\end{array}$ & Protein & $\begin{array}{l}\text { Pollen tube cell wall extension, softening of the stigma and } \\
\text { transmitting tract cells for pollen penetration. }\end{array}$ & [reviewed in S26, S14] \\
\hline $\begin{array}{l}\text { Stigma } \\
\text { Style }\end{array}$ & $\begin{array}{l}\text { Arabinogalactan proteins } \\
\text { (AGP) } \\
\text { (TTS1, TTS2, NaTTS, } \\
\text { PELPIII) }\end{array}$ & Glycoprotein & $\begin{array}{l}\text { Pollen grain germination } \\
\text { Pollen tube nutritive support and attraction } \\
\text { Reproductive barriers } \\
\text { (for PELPIII : Translocated from the pistil to the pollen } \\
\text { tube callose wall to concur in pollen tube growth } \\
\text { Essential for interspecific incompatibility }\end{array}$ & $\begin{array}{l}\text { [S27, S28, S29, S30, S31, S32, S33, } \\
\text { S34, S35] }\end{array}$ \\
\hline Style & $\begin{array}{l}\text { Pectin (weakly } \\
\text { methylesterified) }\end{array}$ & Polysaccharide & $\begin{array}{l}\text { Pollen tube adhesion to the stylar tissues with SCA, } \\
\text { facilitation of pollen tube growth in Lilium longiflorum }\end{array}$ & [S36] \\
\hline Style & $\begin{array}{l}\text { Lipid Transfer Protein: } \\
\text { Stigma/stylar Cystein-rich } \\
\text { adhesin (SCA) }\end{array}$ & Protein & $\begin{array}{l}\text { Pollen tube adhesion to the stylar tissues with pectins, } \\
\text { facilitating pollen tube growth in Lilium longiflorum }\end{array}$ & {$[\mathrm{S} 37, \mathrm{~S} 38, \mathrm{~S} 39, \mathrm{~S} 40]$} \\
\hline Style & AMOR (Methyl-glucuronosyl & Disaccharide & Methyl-glucuronosyl galactose renders competent pollen & [S41] \\
\hline
\end{tabular}




\begin{tabular}{|c|c|c|c|}
\hline & arabinogalactan) & & tube for LURE attraction in Torenia fournieri \\
\hline Ovary & D-serine & Amino acid & $\begin{array}{l}\text { Regulate pollen tube growth via a modulation of pollen } \\
\text { glutamate receptors-like that form calcium channels }\end{array}$ \\
\hline $\begin{array}{l}\text { Ovary } \\
\text { Ovule }\end{array}$ & $\begin{array}{l}\text { Sugar transporter (AtSTP8, } \\
\text { 12) }\end{array}$ & Protein & Ensure sugars uptake in ovules \\
\hline Integument & GABA & Amino acid & Integument pollen tube guidance \\
\hline Synergid cells & Transcription factor MYB98 & Protein & Pollen tube guidance and synergid cell differenciation \\
\hline Synergid cells & $\begin{array}{l}\text { TfLUREs } \\
\text { AtLUREs }\end{array}$ & Peptide & $\begin{array}{l}\text { Micropylar attraction of pollen tubes } \\
\text { Reproductive barrier and isolation }\end{array}$ \\
\hline Synergid cells & $\begin{array}{l}\text { Rapid Alkalinization Factor } \\
\text { (RALF34) }\end{array}$ & Peptide & $\begin{array}{l}\text { Replace the pollen RALF4 \& } 19 \text { on the receptor causing [S48] } \\
\text { rupture of the pollen tube }\end{array}$ \\
\hline Synergid cells & $\begin{array}{l}\text { Egg-apparatus-secreted } \\
\text { polymorphic peptides } \\
\text { (ZmEA1) }\end{array}$ & Peptide & $\begin{array}{l}\text { Micropylar guidance of pollen tubes in Zea mays } \\
\text { Reproductive barrier }\end{array}$ \\
\hline Synergid cells & FERONIA & Protein & Receptor-like kinase required for pollen tube reception \\
\hline Synergid cells & $\begin{array}{l}\text { TURAN } \\
\text { EVAN }\end{array}$ & Protein & $\begin{array}{l}\text { Uridine diphosphate (UDP)-glycosyltransferase and } \\
\text { dolichol kinase involved in protein } N \text {-glycosylation } \\
\text { required for pollen tube reception }\end{array}$ \\
\hline Synergid cells & LORELEI & GPI-anchore & Pollen tube reception \\
\hline Synergid cells & NORTIA & Protein & $\begin{array}{l}\text { A mildew-resistance locus } \mathrm{O} \text { family involved in } \\
\text { FERONIA-dependent pollen tube reception }\end{array}$ \\
\hline
\end{tabular}


Table S3 Main candidate molecules produced by the gametophytes reported to be involved in the pollen-pistil molecular interactions, which may be involved in sexual selection through male-male competition and/or female choice.

\begin{tabular}{|c|c|c|c|c|}
\hline Localization & Molecule Name & $\begin{array}{l}\text { Type of } \\
\text { molecule }\end{array}$ & $\begin{array}{l}\text { Putative function to support pollen } \\
\text { germination and growth }\end{array}$ & References \\
\hline Pollen grain & $\begin{array}{l}\text { S-locus Cystein-Rich, S-locus } \\
\text { protein } 11 \text { (SCR/SP11) }\end{array}$ & Protein & $\begin{array}{l}\text { Male determinant in sporophytic Self- } \\
\text { Incompatibility in Brassicaceae }\end{array}$ & {$[\mathrm{S} 55, \mathrm{~S} 56]$} \\
\hline Pollen grain & NO & $\begin{array}{l}\text { Reactive } \\
\text { Nitrogen Species } \\
\text { (RNS) }\end{array}$ & $\begin{array}{l}\text { NO emission by the pollen grain through apertural } \\
\text { regions concomitantly decreasing } \mathrm{H} 2 \mathrm{O} 2 \text { levels in the } \\
\text { stigma : stigma-pollen interaction }\end{array}$ & {$[\mathrm{S} 20, \mathrm{~S} 21]$} \\
\hline $\begin{array}{l}\text { Pollen grain } \\
\text { Pollen tube }\end{array}$ & Calcium & Mineral & $\begin{array}{l}\text { Spike of calcium after hydration at the potential } \\
\text { germination site and oscillation during pollen tube } \\
\text { growth }\end{array}$ & {$[\mathrm{S} 19, \mathrm{~S} 57]$} \\
\hline $\begin{array}{l}\text { Pollen grain } \\
\text { Pollen tube }\end{array}$ & AtABCG28 (ABC transporter) & Protein & $\begin{array}{l}\text { ROS accumulation at the pollen tube tip. } \\
\text { Involvement in accumulating secretory vesicles } \\
\text { containing polyamines, precursors of ROS }\end{array}$ & [S58] \\
\hline $\begin{array}{l}\text { Pollen grain } \\
\text { Pollen tube }\end{array}$ & $\mathrm{H}_{2} \mathrm{O}_{2}$ & $\begin{array}{l}\text { Reactive Oxygen } \\
\text { Species (ROS) }\end{array}$ & $\begin{array}{l}\text { Accumulation of ROS at the site of pollen tube } \\
\text { emergence and oscillation during pollen tube growth }\end{array}$ & {$[\mathrm{S} 59, \mathrm{~S} 60, \mathrm{~S} 61, \mathrm{~S} 62]$} \\
\hline $\begin{array}{l}\text { Pollen grain } \\
\text { Pollen tube }\end{array}$ & Putrescine, spermine, spermidine & Polyamines & $\begin{array}{l}\text { Modulation of ROS homeostasis, cytoskeleton } \\
\text { assembly and cell wall remodeling }\end{array}$ & [S63] \\
\hline $\begin{array}{l}\text { Pollen grain } \\
\text { Pollen tube }\end{array}$ & PrpS, 20kDa & Protein & $\begin{array}{l}\text { Male determinant in gamatophytic Self- } \\
\text { Incompatibility in Papaver rhoeas }\end{array}$ & [S64] \\
\hline $\begin{array}{l}\text { Pollen grain } \\
\text { Pollen tube }\end{array}$ & $\begin{array}{l}\text { Phosphatidic acid (PA) and } \\
\text { Phosphoinositides : PtdIns3P } \\
\text { (Phosphatidylinositol 3- } \\
\text { phosphate); PtdIns(3,5)P2 } \\
\text { (Phosphatidylinositol 3,5- } \\
\text { bisphosphate); PtdIns(4,5)P2 } \\
\text { (Phosphatidylinositol (4,5)- } \\
\text { bisphosphate) }\end{array}$ & Phospholipids & $\begin{array}{l}\text { Membrane and vesicle components influencing the } \\
\text { biophysical properties. Involved in lipid-mediated } \\
\text { signaling, exocytosis, orientation of tip growth and } \\
\text { recycling endosomes in association with exocyst } \\
\text { complex (SEC and EXO). PtdIns(4,5)P2 acts } \\
\text { upstream of ROP by promoting plasma membrane } \\
\text { localisation of GTP-Rop }\end{array}$ & {$[\mathrm{S} 65, \mathrm{~S} 66, \mathrm{~S} 67, \mathrm{~S} 68, \mathrm{~S} 69]$} \\
\hline
\end{tabular}




\begin{tabular}{|c|c|c|c|c|}
\hline $\begin{array}{l}\text { Pollen grain } \\
\text { Pollen tube }\end{array}$ & Serine/threonine kinase & Protein & Pollen germination and pollen tube growth & {$[\mathrm{S} 70]$} \\
\hline $\begin{array}{l}\text { Pollen grain } \\
\text { Pollen tube }\end{array}$ & $\begin{array}{l}\text { Rho Family small GTPase (ROP) } \\
\text { and ROP-interactive proteins (RIP) }\end{array}$ & Protein & $\begin{array}{l}\text { Marks pollen germination sites and leads the } \\
\text { oscillatory polarized tube growth }\end{array}$ & {$[\mathrm{S} 71]$} \\
\hline $\begin{array}{l}\text { Pollen grain } \\
\text { Pollen tube }\end{array}$ & Exocyst complex (SEC3A) & Protein & $\begin{array}{l}\text { Fundamental role in spatial regulation of polar } \\
\text { exocytosis. Ensure correct delivery of cell wall } \\
\text { material during pollen germination and growth. }\end{array}$ & {$[\mathrm{S} 72]$} \\
\hline $\begin{array}{l}\text { Pollen grain } \\
\text { Pollen tube }\end{array}$ & $\begin{array}{l}\text { Vacuolar Protein sorting } 41 \\
\text { (VSP41) }\end{array}$ & Protein & $\begin{array}{l}\text { Mediated late stage of the endocytic pathway is } \\
\text { essential for male-female interaction in Arabidopsis }\end{array}$ & {$[\mathrm{S} 73]$} \\
\hline $\begin{array}{l}\text { Pollen grain } \\
\text { Pollen tube }\end{array}$ & $\begin{array}{l}\text { Aquaporins: NODULIN 26-like } \\
\text { Intrinsic Proteins (NIP4), Tonoplast } \\
\text { Intrinsic Proteins (TIP1 \& 5), } \\
\text { Small and basic intrinsic proteins } \\
\text { (SIP2) }\end{array}$ & Protein & $\begin{array}{l}\text { Water intake channels involved in self- } \\
\text { incompatibility response, pollen hydration, } \\
\text { germination and pollen tube growth }\end{array}$ & {$[\mathrm{S} 74, \mathrm{~S} 75, \mathrm{~S} 76, \mathrm{~S} 77, \mathrm{~S} 78]$} \\
\hline $\begin{array}{l}\text { Pollen grain } \\
\text { Pollen tube }\end{array}$ & Expansins & Protein & $\begin{array}{l}\text { Remodeling proteins that soften stigma cell walls for } \\
\text { pollen tube penetration }\end{array}$ & {$[\mathrm{S} 79]$} \\
\hline $\begin{array}{l}\text { Pollen grain } \\
\text { Pollen tube }\end{array}$ & VANGUARD, PPME1, PME48 & Protein & $\begin{array}{l}\text { Pectin methylesterases control the cell wall plasticity } \\
\text { and rigidity (via calcium bridging between } \\
\text { deesterified pectins) to ensure pollen grain } \\
\text { germination and pollen tube growth }\end{array}$ & {$[\mathrm{S} 80, \mathrm{~S} 81, \mathrm{~S} 82]$} \\
\hline $\begin{array}{l}\text { Pollen grain } \\
\text { Pollen tube }\end{array}$ & $\begin{array}{l}\text { Pectin methylesterase Inhibitors } \\
\text { (BoPMEI1) }\end{array}$ & Protein & $\begin{array}{l}\text { Regulation of Pectin methylesterase activity } \\
\text { influencing cell wall plasticity during growth. }\end{array}$ & {$[\mathrm{S} 83]$} \\
\hline $\begin{array}{l}\text { Pollen grain } \\
\text { Pollen tube }\end{array}$ & Glycoside Hydrolase & Protein & $\begin{array}{l}\text { Cell wall remodeling enzymes controlling the pollen } \\
\text { tube cell wall mechanical properties to ensure } \\
\text { growth. }\end{array}$ & [reviewed in S26] \\
\hline Pollen tube & $\begin{array}{l}\text { Skp1-Cullin1-F-box protein S- } \\
\text { locus F-box }\left(\mathrm{SCF}^{\mathrm{SLF}}\right)\end{array}$ & Proteins & $\begin{array}{l}\text { Male determinant in gametophytic Self- } \\
\text { Incompatibility in Solanaceae }\end{array}$ & {$[\mathrm{S} 84, \mathrm{~S} 85]$} \\
\hline Pollen tube & $\begin{array}{l}\text { Leucine rich repeat extensins } \\
(\mathrm{LRX}) / \mathrm{RLK}\end{array}$ & Proteins & $\begin{array}{l}\text { Pollen germination and pollen tube growth. Control } \\
\text { cell wall integrity and interact with RALF }\end{array}$ & [S86, S87, S88] \\
\hline Pollen tube & $\begin{array}{l}\text { Rapid Alkalinization Factors } \\
\text { (RALF4 \&19) }\end{array}$ & Peptide & $\begin{array}{l}\text { Regulate pollen tube cell wall integrity and growth. } \\
\text { Interact with LRX or BUPS (Buddha’s Paper Seal) }\end{array}$ & [S86, S89, S48] \\
\hline
\end{tabular}




\begin{tabular}{|c|c|c|c|c|}
\hline Pollen tube & $\begin{array}{l}\text { Ions, small osmolytes and } \\
\text { mechanosensitive channels }\end{array}$ & Protein & Pollen tube growth & $\begin{array}{l}\text { [S90, S91, S92, S93, S94, S95, } \\
\text { S96] }\end{array}$ \\
\hline Pollen tube & Glutamate receptors-like & Protein & $\begin{array}{l}\text { Form calcium channels that regulate pollen tube } \\
\text { growth in response to D-Serine originating from the } \\
\text { pistil }\end{array}$ & {$[\mathrm{S} 42]$} \\
\hline Pollen tube & Alkaline ceramidase (TOD1) & Protein & Regulation of turgor pressures & [S97] \\
\hline Pollen tube & O-fucosyltransferases (AtOFT1) & Protein & $\begin{array}{l}\text { Facilitate penetration of pollen tubes through the } \\
\text { stigma style interface }\end{array}$ & [S98] \\
\hline Pollen tube & AtLTP5 & Protein & Pollen tube growth & [S99] \\
\hline Pollen tube & $\begin{array}{l}\text { Receptor-Like Kinases (RLKs): } \\
\text { PRK, ANXUR, MARIS, } \\
\text { Male discoverer (MDIS), Male dis- } \\
\text { coverer-interacting receptor-like } \\
\text { kinase (MIK), Lost in pollen tube } \\
\text { guidance (LIP), Buddha’s Paper } \\
\text { Seal (BUPS) }\end{array}$ & Protein & $\begin{array}{l}\text { Pollen pistil interaction, pollen tube growth and } \\
\text { guidance. Perception of the signaling micropylar } \\
\text { guidance of LURE peptides or pollen and ovule } \\
\text { RALF peptides, maintain cell wall integrity }\end{array}$ & $\begin{array}{l}\text { [S100, S101, S102, S103, S104, } \\
\text { S105, S48] }\end{array}$ \\
\hline Pollen tube & TURAN & Protein & $\begin{array}{l}\text { Uridine diphosphate (UDP)-glycosyltransferase } \\
\text { involved in protein } N \text {-glycosylation. TURAN is } \\
\text { involved in pollen tube integrity and targets } \\
\text { ANXUR. }\end{array}$ & {$[\mathrm{S} 52]$} \\
\hline Pollen tube & $\begin{array}{l}\text { Respiratory burst oxidative } \\
\text { homologs (NADPH oxidases) }\end{array}$ & Protein & $\begin{array}{l}\text { Participate in regulating Redox signaling during } \\
\text { polarized growth of pollen tube. Act together with } \\
\text { Receptor like Kinase and calcium channels }\end{array}$ & {$[\mathrm{S} 60, \mathrm{~S} 61]$} \\
\hline Pollen tube & $\begin{array}{l}\text { Sugar transporter (AtSTP2, 4, 6, 7, } \\
\text { 8, 9, 10, 11, CsHT1) }\end{array}$ & Protein & Ensure sugars intake during pollen tube growth & {$[S 106, \mathrm{~S} 107, \mathrm{~S} 43]$} \\
\hline
\end{tabular}




\section{Supplementary references :}

S1 Hedhly, A. et al. (2005) Influence of genotype temperature interaction on pollen performance. J. Evol. Biol. 18, 1494-1502

S2 Snow, A.A. and Spira, T.P. (1991) Differential pollen-tube growth rates and nonrandom fertilization in Hibiscus moscheutos (Malvaceae). Am. Jour. Bota. 78, 1419-1426

S3 Pasonen, H.L. et al. (1999) Pollen-tube growth rate and seed-siring success among Betula pendula clones. New Phytol. 143, $243-251$

S4 Marshall, D.L. and Ellstrand, N.C. (1988) Effective mate choice in wild radish: evidence for selective seed abortion and its mechanism. Am. Nat. 131, 736-759

S5 Marshall, D.L. (1998) Pollen donor performance can be consistent across maternal plants in wild radish (Raphanus sativus, Brassicaceae): a necessary condition for the action of sexual selection. Am. Jour. Bota. 85, 1389-1397

S6 Melser, C. et al. (1997) Selection on pollen donors by Echium vulgare (Boraginaceae). Sex. Plant Repro. 10, 305-312

S7 Skogsmyr, I. and Lankinen, Å. (2000) Potential selection for female choice in Viola tricolor. Evol. Ecol. Res. 2, 965-979

S8 Nakamura, R.R. and Wheeler, N.C. (1992) Self-fertility variation and paternal success through outcrossing in Douglas fir. Theo. App. Gene. 83, 851-854

S9 Nakamura, R.R. and Wheeler, N.C. (1992) Pollen competition and paternal success in Douglas-fir. Evolution 46, 846-851

S10 Cruzan, M.B. (1990) Variation in pollen size, fertilization ability, and postfertilization siring ability in Erythronium grandiflorum. Evolution 44, 843-856

S11 Albert, B. et al. (2018) Effect of aperture number on pollen germination, survival and reproductive success in Arabidopsis thaliana. Ann. Bota. $121,733-740$

S12 Stein J. C. et al. (1991) Molecular cloning of a putative receptorprotein kinase gene encoded at the self-incompatibility locus of Brassica oleracea. Proc. Natl. Acad. Sci. U. S. A. 88, 8816-8820 
S13 Goring, D.R. and Rothstein, S.J. (1992) The S-locus receptorkinase gene in a self-incompatible Brassica napusline en-codes a functional serine/threonine kinase. Plant Cell 4, 1273-1281

S14 Coulter, A. et al. (2012) Pollination drops as dynamic apoplastic secretions. Flora. Distri. Funct. Ecol. Plant. 207, 482-490

S15 Pezzotti, M. et al. (2002) Pollination modulates expression of the PPAL gene, a pistil-specific $\beta$-expansin. Plant Mole. Biol. 49, 187-197

S16 Nieuwland, J. et al. (2005) Lipid transfer proteins enhance cell wall extension in tobacco. Plant Cell 17, 2009-2019

S17 Kim, S. et al. (2003) Chemocyanin, a small basic protein from the lily stigma, induces pollen tube chemotropism. Proc. Natl. Acad. Sci. U. S. A. 100, 16125-16130

S18 Dong, J. et al. (2005) Plantacyanin plays a role in reproduction in Arabidopsis. Plant Physio. 138, 778-789

S19 Iwano, M. et al. (2004) Ca2+ dynamics in a pollen grain and papilla cell during pollination of Arabidopsis. Plant Physio. 136, 3562-3571

S20 McInnis S.M. et al. (2006) Production of reactive oxygen species and reactive nitrogen species by angiosperm stigmas and pollen: potential signalling crosstalk? New Phytol. 172, 221-228

S21 Hiscock S. et al. (2007) Signaling on the stigma: Potential new roles for ROS and NO in plant cell signaling. Plant Signa. Beha. 2, 23-24

S22 Zafra A. et al. (2016) Patterns of ROS accumulation in the stigmas of Angiosperms and visions into their multi-functionality in plant reproduction. Front. Plant Sci. 7, 1112

S23 Zafra, A. et al. (2010) Cellular localization of ROS and NO in olive reproductive tissues during flower development. BMC Plant Biol. 19, 1-14

S24 McClure B.A. et al. (1989) Style self-incompatibility gene products of Nicotiana alataare ribonucleases. Nature 342, 955-957

S25 Foote, H.C. et al. (1994) Cloning and expression of a distinctive class of self-incompatibility (S) gene from Papaver rhoeas L. Proc. Natl. Acad. Sci. U. S. A. $91,2265-2269$

S26 Mollet, J.C. et al. (2013) Cell wall composition, biosynthesis and remodeling during pollen tube growth. Plants 2, 107-147

S27 Cheung, A.Y. et al. (1995) A floral transmitting tissue-specific grycoprotein attracts pollen tubes and stimulate their growth. Cell 82, 383-393 
S28 Wu, H.M. et al. (1995) A pollen tube growth stimulatory glycoprotein is deglycosylated by pollen tubes and displays a glycosylation gradient in the flower. Cell 82, 395-403

S29 Wu, H.M. et al. (2000) A pollen tube growth promoting arabinogalactan protein from Nicotiana alata is similar to the tobacco TTS protein. Plant Journal 22, 165-176

S30 De Graaf, B.H. et al. (2003) Characterization and localization of the transmitting tissue specific PELPIII proteins of Nicotiana tabacum. J. Exp. Bota. 54, 55-63

S31 Losada, J.M. and Herrero, M. (2012) Arabinogalactan-protein secretion is associated with the acquisition of stigmatic receptivity in the apple flower. Ann. Bota. 110, 573-584

S32 Eberle, C.A. et al. (2013) PELPIII: the class III pistil specific extensin like Nicotiana tabacum proteins are essential for interspecific incompatibility. Plant Jour. 74, 805-814

S33 Losada, J.M. et al. (2014) Arabinogalactan proteins mark stigmatic receptivity in the protogynous flowers of Magnolia virginiana (Magnoliaceae). Am. Jour. Bota. 101, 1963-1975

S34 Pereira, A.M. et al. (2015) Arabinogalactan proteins: rising attention from plant biologists. Plant Repro. 28, 1-15

S35 Callaway, T. D., \& Singh-Cundy, A. (2019) HD-AGPs as speciation genes: positive selection on a proline-rich domain in non-hybridizing species of Petunia, Solanum, and Nicotiana. Plants 8, 211

S36 Mollet, J.C. et al. (2000) A lily stylar pectin is necessary for pollen tube adhesion to an in vitro stylar matrix. Plant Cell 12, 1737-1749

S37 Park, S.Y. et al. (2000) A lipid transfer-like protein is necessary for lily pollen tube adhesion to an in vitro stylar matrix. Plant Cell 12, 151-163

S38 Park, S.Y. and Lord, E.M. (2003) Expression studies of SCA in lily and confirmation of its role in pollen tube adhesion. Plant Mol. Biol. 51, 183189

S39 Chae, K. et al. (2007) Two SCA (stigma/style cysteine-rich adhesin) isoforms show structural differences that correlate with their levels of in vitro pollen tube adhesion activity. J. Biol. Chem. 282, 33845-33858 
S40 Chae, K. and Lord, E.M. (2011) Pollen tube growth and guidance: roles of small, secreted proteins. Ann. Bota. 108, 627-636

S41 Mizukami, A.G. et al. (2016) The AMOR arabinogalactan sugar chain induces pollen-tube competency to respond to ovular guidance. Current Biology 26, 1091-1097

S42 Michard, E. et al. (2011) Glutamate receptor-like genes form Ca2+ channels in pollen tubes and are regulated by pistil D serine. Science 332, 434-437

S43 Rottmann, T. et al. (2018) Glucose uptake via STP transporters inhibits in vitro pollen tube growth in a HEXOKINASE1-dependent manner in Arabidopsis thaliana. Plant Cell 30, 2057-2081

S44 Palanivelu, R. et al. (2003) Pollen tube growth and guidance is regulated by POP2, an Arabidopsis gene that controls GABA levels. Cell 114, 4759

S45 Kasahara, R.D. et al. (2005) MYB98 is required for pollen tube guidance and synergid cell differentiation in Arabidopsis. Plant Cell 17, 29812992

S46 Okuda, S. et al. (2009) Defensin-like polypeptide LUREs are pollen tube attractants secreted from synergid cells. Nature 458, 357-361

S47 Zhong, S. et al. (2019) Cysteine-rich peptides promote interspecific genetic isolation in Arabidopsis. Science 364, 6443

S48 Ge, Z. et al. (2017) Arabidopsis pollen tube integrity and sperm release are regulated by RALF-mediated signaling. Science 358, 1596-1600

S49 Márton, M.L. et al. (2005) Micropylar pollen tube guidance by egg apparatus 1 of maize. Science 307, 573-576

S50 Márton, M.L. et al. (2012) Overcoming hybridization barriers by the secretion of the maize pollen tube attractant ZmEA1 from Arabidopsis ovules. Current Biology 22, 1194-1198

S51 Escobar-Restrepo, J.M. et al. (2007) The FERONIA receptor-like kinase mediates male-female interactions during pollen tube reception. Science 317, 656-660

S52 Lindner, H. et al. (2015) TURAN and EVAN mediate pollen tube reception in Arabidopsis synergids through protein glycosylation. PLoS Biol. 13, e1002139 
S53 Capron, A. et al. (2008) Maternal control of male-gamete delivery in Arabidopsis involves a putative GPI-anchored protein encoded by the LORELEI gene. Plant Cell 20, 3038-3049

S54 Kessler, S.A. et al. (2010) Conserved molecular components for pollen tube reception and fungal invasion. Science 330, 968-971

S55 Schopfer C.R. et al. (1999) The male determinant of self-incompatibility in Brassica. Science 286, 1697-1700

S56 Takayama S. et al. (2000) The pollen determinant of self-incompatibility in Brassica campestris. Proc. Natl. Acad. Sci. U. S. A. 97, 1920-1925

S57 Iwano, M. et al. (2009) Fine-tuning of the cytoplasmic Ca2+ concentration is essential for pollen tube growth. Plant Physio. 150, 1322-1334

S58 Do, T.H.T. et al. (2019) Arabidopsis ABCG28 is required for the apical accumulation of reactive oxygen species in growing pollen tubes. Proc. Natl. Acad. Sci. U. S. A. 116, 12540-12549

S59 Speranza, A. et al. (2012) Reactive oxygen species are involved in pollen tube initiation in kiwifruit. Plant Biology 14, 64-76

S60 Boisson-Dernier, A. et al. (2013) ANXUR receptor-like kinases coordinate cell wall integrity with growth at the pollen tube tip via NADPH oxidases. PLoS Biol 11, e1001719

S61 Kaya H. et al. (2014) $\mathrm{Ca}^{2+}$-Activated reactive oxygen species production by Arabidopsis RbohH and RbohJ is essential for proper pollen tube tip growth. Plant Cell 26, 1069-1080

S62 Pasqualini, S. et al. (2015) Roles for NO and ROS signalling in pollen germination and pollen-tube elongation in Cupressus arizonica. Biol. Planta. 59, 735-744

S63 Aloisi, I. et al. (2016) Polyamines in pollen: from microsporogenesis to fertilization. Front. Plant Sci. 7, 155

S64 Wheeler, M.J. et al. (2009) Identification of the pollen self-incompatibility determinant in Papaver rhoeas. Nature 459, 992-995

S65 Sousa, E. et al. (2008) Arabidopsis phosphatidylinositol-4-monophosphate 5-kinase 4 regulates pollen tube growth and polarity by modulating membrane recycling. Plant Cell 20, 3050-3064

S66 Gao, X.Q. and Zhang, X.S. (2012) Metabolism and roles of phosphatidylinositol 3-phosphate in pollen development and pollen tube growth in Arabidopsis. Plant Signaling Behavior 7, 165-169 
S67 Bloch, D. et al. (2016) Exocyst SEC3 and phosphoinositides define sites of exocytosis in pollen tube initiation and growth. Plant Physio. 172, 980-1002

S68 Sekereš, J. et al. (2017) Analysis of exocyst subunit EXO70 family reveals distinct membrane polar domains in tobacco pollen tubes. Plant Physio. 173, 1659-1675

S69 Scholz, P. et al. (2020) Signalling Pinpointed to the Tip: The Complex Regulatory Network That Allows Pollen Tube Growth. Plants 9, 1098

S70 Huang, J.T. et al. (2017) Competitive ability of maize pollen grains requires paralogous serine threonine protein kinases STK1 and STK2. Genetics 207, 1361-1370

S71 Li, S. et al. (2008) RIP1 (ROP Interactive Partner 1)/ICR1 marks pollen germination sites and may act in the ROP1 pathway in the control of polarized pollen growth. Molecular Plant 1, 1021-1035

S72 Li, Y. et al. (2017) Exocyst subunit SEC3A marks the germination site and is essential for pollen germination in Arabidopsis thaliana. Sci. Rep. 7, 1-11

S73 Hao, L. et al. (2016) AtVPS41-mediated endocytic pathway is essential for pollen tube-stigma interaction in Arabidopsis. Proc. Natl. Acad. Sci. U. S. A. 113, 6307-6312

S74 Ikeda, S. et al. (1997) An aquaporin-like gene required for the Brassica self-incompatibility response. Science 276, 1564-1566

S75 Soto, G. et al. (2010) TIP5; 1 is an aquaporin specifically targeted to pollen mitochondria and is probably involved in nitrogen remobilization in Arabidopsis thaliana. Plant Journal 64, 1038-1047

S76 Maurel C. et al. (2015) Aquaporins in plants. Physio. Rev. 95, 1321-1358

S77 Di Giorgio, J.A.P. (2016) Pollen-specific aquaporins NIP4; 1 and NIP4; 2 are required for pollen development and pollination in Arabidopsis thaliana. Plant Cell 28, 1053-1077

S78 Sato, R. and Maeshima, M. (2019) The ER-localized aquaporin SIP2; 1 is involved in pollen germination and pollen tube elongation in Arabidopsis thaliana. Plant Mole. Biol. 100, 335-349 
S79 Cosgrove, D.J. et al. (1997) Group I allergens of grass pollen as cell wall-loosening agents. Proc. Natl. Acad. Sci. U. S. A. 94, 6559-6564

S80 Jiang, L. et al. (2005) VANGUARD1 encodes a pectin methylesterase that enhances pollen tube growth in the Arabidopsis style and transmitting tract. Plant Cell 17, 584-596

S81 Tian, G.W. et al. (2006) Pollen-specific pectin methylesterase involved in pollen tube growth. Devel. Biol. 294, 83-91

S82 Leroux, C. et al. (2015) PECTIN METHYLESTERASE48 is involved in Arabidopsis pollen grain germination. Plant Physio. 167, 367-380

S83 Zhang, G.Y. et al. (2010) BoPMEI1, a pollen-specific pectin methylesterase inhibitor, has an essential role in pollen tube growth. Planta 231, 1323-1334

S84 Sijacic P. et al. (2004) Identification of the pollen determinant of S-RNase-mediated self-incompatibility. Nature 429, 302-305

S85 Kubo K. et al. (2010) Collaborative non-self recognition system in S-RNase-based self-incompatibility. Science 330, 796-799

S86 Mecchia, M.A. et al. (2017) RALF4/19 peptides interact with LRX proteins to control pollen tube growth in Arabidopsis. Science 358, 16001603

S87 Fabrice, T.N. et al. (2018) LRX proteins play a crucial role in pollen grain and pollen tube cell wall development. Plant Physiol. 176, 1981-1992

S88 Wang, X. et al. (2018) Pollen-expressed leucine-rich repeat extensins are essential for pollen germination and growth. Plant Physiol. 176, 19932006

S89 Ge, Z. et al. (2017) Arabidopsis pollen tube integrity and sperm release are regulated by RALF-mediated signaling. Science 358, 1596-1600

S90 Dutta, R. and Robinson, K.R. (2004) Identification and characterization of stretch-activated ion channels in pollen protoplasts. Plant Physiol 135, 1398-1406

S91 Hamilton, E.S. et al. (2015) Mechanosensitive channel MSL8 regulates osmotic forces during pollen hydration and germination. Science 350, 438-441

S92 Breygina, M.A. et al. (2016) Hydrogen peroxide affects ion channels in lily pollen grain protoplasts. Plant Biol. 18, 761-767

S93 Michard E. et al. (2017) Signaling with ions: the keystone for apical cell growth and morphogenesis in pollen tubes. Plant Physio. 173, 91-111 
S94 Gutermuth, T. et al. (2018) Tip localized Ca2+ permeable channels control pollen tube growth via kinase dependent R and S type anion channel regulation. New Phytol. 218, 1089-1105

S95 Feijo, J.A. (2020) Signaling through ions is essential for chemotropism and reproduction. Biophy. Jour. 118, 94a

S96 Chen, L.Y. et al. (2015) The Arabidopsis alkaline ceramidase TOD1 is a key turgor pressure regulator in plant cells. Nat. Commun. 6, 1-10

S97 Smith, D.K. et al. (2018) A putative protein O-fucosyltransferase facilitates pollen tube penetration through the stigma-style interface. Plant Physio. 176, 2804-2818

S98 Chae, K. et al. (2009) A gain-of-function mutation of Arabidopsis lipid transfer protein 5 disturbs pollen tube tip growth and fertilization. Plant Cell 21, 3902-3914

S99 Boisson-Dernier, A. et al. (2009) Disruption of the pollen-expressed FERONIA homologs ANXUR1 and ANXUR2 triggers pollen tube discharge. Development 136, 3279-3288

S100 Boisson-Dernier, A. et al. (2015) Receptor-like cytoplasmic kinase MARIS functions downstream of CrRLK1L-dependent signaling during tip growth. Proc. Natl. Acad. Sci. U. S. A. 112, 12211-12216

S101 Liu, J. et al. (2013) Membrane-bound RLCKs LIP1 and LIP2 are essential male factors controlling male-female attraction in Arabidopsis. Current Biology 23, 993-998

S102 Takeuchi, H. and Higashiyama, T. (2016) Tip-localized receptors control pollen tube growth and LURE sensing in Arabidopsis. Nature 531, $245-248$

S103 Wang, T. et al. (2016) A receptor heteromer mediates the male perception of female attractants in plants. Nature 531, 241-244

S104 Zhang, X. et al. (2017) Structural basis for receptor recognition of pollen tube attraction peptides. Nat. Commun. 8, 1-9

S105 Ylstra, B et al. (1998) Hexose transport in growing petunia pollen tubes and characterization of a pollen-specific, putative monosaccharide transporter. Plant Physio. 118, 297-304

S106 Cheng, J. et al. (2015) Down-regulating CsHT1, a cucumber pollen-specific hexose transporter, inhibits pollen germination, tube growth, and seed development. Plant Physio. 168, 635-647 
S107 Rottmann, T. et al. (2016) STP10 encodes a high-affinity monosaccharide transporter and is induced under low-glucose conditions in pollen tubes of Arabidopsis. J. Exp. Bota. 67, 2387-2399 